\title{
Molecular biology of coronaviruses: an overview of virus-host interactions and pathogenesis
}

\author{
Paloma Hidalgo ${ }^{1}$, Margarita Valdés ${ }^{2}$, and Ramón A. González ${ }^{1 *}$ \\ ${ }^{1}$ Centro de Investigación en Dinámica Celular, Instituto de Investigación en Ciencias Básicas y Aplicadas, Universidad Autónoma del Estado de \\ Morelos; ${ }^{2}$ Unidad de Diagnóstico y Medicina Molecular, Hospital del Niño Morelense. Morelos, Mexico
}

\begin{abstract}
Coronaviruses (CoV) are enveloped, plus-strand RNA viruses that have the largest known RNA genomes and infect birds and mammals, causing various diseases. Human coronaviruses (HCoVs) were first identified in the mid-1960s and have been known to cause enteric or respiratory infections. In the last two decades, three HCoVs have emerged, including the severe acute respiratory syndrome coronavirus 2 (SARS-CoV-2), which initiated the ongoing pandemic. SARS-CoV-2 causes a respiratory illness that presents as a mild upper respiratory disease but may result in acute respiratory distress syndrome, multi-organ failure and can be fatal, especially when underlying comorbidities are present. Children account for a low percentage of coronavirus disease 2019 (COVID-19) cases, with seemingly less severe disease. Most pediatric patients present mild or moderate symptoms or are asymptomatic. However, some cases may be severe. Therefore, SARS-CoV-2 infection and COVID-19 in pediatric patients must be studied in detail. This review describes general features of the molecular biology of CoVs and virus-host interactions that may be implicated in the pathogenesis of SARS-CoV-2.
\end{abstract}

Key words: SARS-CoV-2. Endemic coronaviruses. Epidemic coronaviruses. Virus-host interactions. COVID-19 in children. Pathogenesis.

\section{Biología molecular de los coronavirus: una visión panorámica de las interacciones virus-hospedero y de la patogénesis}

\section{Resumen}

Los coronavirus son virus envueltos de ARN de polaridad positiva, con los genomas más grandes que se conocen. Infectan aves y mamíferos, y causan una amplia variedad de enfermedades. Los coronavirus humanos se identificaron a mediados de la década de 1960 y se sabe que causan infecciones entéricas y respiratorias. En las últimas dos décadas han emergido tres coronavirus humanos pandémicos, incluido el coronavirus 2 del síndrome agudo respiratorio grave (SARS-CoV-2) que ha causado la pandemia actual. EI SARS-CoV-2 produce enfermedad respiratoria que se presenta con padecimientos moderados de las vías respiratorias altas, pero puede resultar en síndrome respiratorio agudo, falla multiorgánica y muerte, en especial en casos con morbilidad subyacente. Los casos de COVID-19 en niños representan un porcentaje bajo y con síntomas menos graves de la enfermedad. La mayoría de los pacientes pediátricos son asintomáticos o presentan enfermedad leve o moderada; sin embargo, también en niños la enfermedad puede ser grave, por lo que la infección con SARS-CoV-2 y la COVID-19 en pacientes pediátricos deben estudiarse con detalle. En esta revisión se describen las características 
generales de la biología molecular de los coronavirus y de las interacciones virus-hospedero que se conocen para los coronavirus humanos identificados previamente, y que podrían estar implicados en la patogénesis del SARS-CoV-2.

Palabras clave: SARS-CoV-2. Coronavirus endémicos. Coronavirus epidémicos. Interacciones virus-hospedero. COVID-19 en niños. Patogénesis.

\section{Introduction}

Coronaviruses (CoVs) have been studied for nearly nine decades. They have long been associated with a wide variety of respiratory, gastrointestinal (GI), neurological, and multisystemic diseases in many animal species, including humans. Human coronaviruses (HCoVs) were identified shortly after the initial description of many respiratory viruses that cause respiratory diseases during the 1960s. By the 1990s, many aspects of the basic molecular biology, epidemiology, and pathogenesis had been explored. It was clear that their mutation and recombination rates made these viruses highly adaptable to changing tropism and transmission through zoonotic events with epidemic and pandemic potential.

CoVs, which belong to the Nidovirales order, are characterized by the production of nested subgenomic mRNAs and many viral proteins involved in proteolytic processing, genome replication, and subgenomic mRNA synthesis that implicate a highly complex viral replication cycle. They are enveloped, plus-strand RNA viruses with the largest known RNA genomes and infect birds and mammals. The Coronavirinae sub-family is divided into four genera, including the alpha- and beta-CoVs. From these genera, seven CoVs that infect humans are known: 229E, NL63, OC43, HKU1, severe acute respiratory syndrome coronavirus (SARS-CoV), Middle East respiratory syndrome coronavirus (MERSCoV), and SARS-CoV-2. HCoVs have been known to cause enteric or respiratory infections.

In contrast to the four endemic HCoVs (HCoV-229E, HCoV-NL63, HCoV-OC43, HCoV-HKU1), three epidemic HCoVs have emerged in humans in the last two decades, including the SARS-CoV-2 virus that causes the coronavirus disease (COVID-19). The disease rapidly spread worldwide and was declared a pandemic by the World Health Organization in March 2020. This HCoV causes a mild upper respiratory illness or pneumonia. In older patients and those with underlying comorbidities, the infection often results in acute respiratory distress syndrome (ARDS), multi-organ failure, and death. Recent findings have shown that children account for approximately $1-5 \%$ of diagnosed COVID-19 cases, in whom COVID-19 disease seems to be less severe. Although approximately $90 \%$ of pediatric patients are asymptomatic or present mild or moderate symptoms, up to $6.7 \%$ of cases may be severe. The epidemiological and clinical patterns of SARS-CoV-2 infection and COVID-19 in pediatric patients remain unclear, highlighting the urgent need to advance our knowledge on all aspects of the replication of this virus and its interactions with the host. This review aims to provide a brief description of the molecular biology of CoVs and previously identified HCoVs, which have served as the basis to understand the pathogenesis of SARS-CoV-2 and COVID-19.

\section{Historical perspective on CoVs}

CoVs have long been associated with a broad spectrum of diseases in animals and humans. Detailed descriptions of this family of viruses have been included in many excellent reviews ${ }^{1-8}$. They were first reported in 1933, resulting from studies on infectious laryngotracheitis or gasping disease-a lethal respiratory disease of chickens-which eventually led to the identification and cultivation of the infectious bronchitis virus (IBV) that would become the prototype of this family of viruses ${ }^{9-11}$. Subsequently, other CoVs were found to cause GI diseases. In the late 1940s and early 1950s, two related murine CoVs were identified: a virus causing encephalomyelitis in mice called JHM (after Professor J.H. Mueller) and the mouse hepatitis virus $(\mathrm{MHV})^{12-14}$. Although MHV and JHM were initially considered to be potentially useful models for studies on human hepatitis and demyelinating encephalitis, their relationship with these diseases in humans was not demonstrated at the time. However, antibodies that cross-reacted with MHV were found in studies with human serum ${ }^{15}$. By the early 1960s, many currently known viruses that caused respiratory disease were identified, including adenoviruses, influenza A, B, and C, para-influenza 1, 2, 3, and 4, respiratory syncytial viruses, and rhinoviruses. However, since these agents were isolated and cultured from about one-third of the cases of common colds or related illnesses, other cases were suspected to be caused by additional unidentified viruses that could not be cultured. Cultures from the human embryonic trachea or nasal epithelium led to the isolation of the B814 virus strain, which was unrelated to any known respiratory viruses 
Table 1. Human coronaviruses

\begin{tabular}{|l|l|l|l|l|}
\hline Coronaviridae & Strains & Receptor & Animal host & Date identified (year) \\
\hline Alpha-coronavirus & $\begin{array}{l}\text { HCoV-229E } \\
\text { HCoV-NL63 }\end{array}$ & $\begin{array}{l}\text { Human aminopeptidase N (CD13) } \\
\text { ACE2 }\end{array}$ & $\begin{array}{l}\text { Bats } \\
\text { Palm civets, Bats }\end{array}$ & $\begin{array}{l}1966 \\
2004\end{array}$ \\
\hline \multirow{2}{*}{ Beta-coronavirus } & HCoV-OC43 & 9-0-Acetylated sialic acid & Cattle & 1967 \\
& $\begin{array}{l}\text { HcoV-HKU1 } \\
\text { SARS-CoV }\end{array}$ & 9-0-Acetylated sialic acid & Mice & 2005 \\
& MERS-CoV & DPP2 & Palm civets, Bats & 2003 \\
& SARS-CoV2 & ACE2 & Bats, Camels & 2012 \\
\hline
\end{tabular}

and was suspected to be a myxovirus because it proved to be ether-labile ${ }^{16}$. Other strains were later identified in organ cultures $(\mathrm{OC})$, but only two could be successfully grown in the brain of suckling mice, OC 43 and $38^{17}$, which would eventually be adapted to grow in cell monolayers. Simultaneously, other agents were isolated from medical students with a common cold and grown as cell cultures, from which the 229E strain was selected and became the prototype strain ${ }^{18}$. Studies on the antigenic relation, electron microscopy of viral particles, and the cytopathic effect observed in infected cells showed similarity between the IBV, MHV, and the human B814 and 229E strains. Therefore, they were considered a related group of viruses named CoVs because of their morphological appearance resembling the solar corona ${ }^{19}$. The three decades that followed showed significant advances in the biology of $\mathrm{CoVs}^{20-23}$. CoVs were identified in many animal species of birds and mammals, and their potential for zoonotic transmission between species became apparent. For example, in the case of the known $\mathrm{HCoV}$ strains, HCoV-229E originated in bats and was transmitted to humans through alpacas, and the HCoV-OC43 passed from rodents to humans through cattle. Advances in the molecular biology of CoVs also showed high rates of viral genome mutation and recombination, making CoVs highly flexible to adaptation, changing tissue tropism, and hosts.

The viral pathogenic potential ranges from respiratory or GI diseases to hepatitis, encephalomyelitis, vasculitis, coagulopathies, and neurological damage. The disease's severity could often be related to immunopathological aspects of the antiviral response and underlying risk factors. However, since most human infections led to only moderate disease, $\mathrm{HCoV}$ was considered more a nuisance than a threat to human health. In 2002, the zoonotic SARS-CoV-originated in bats and passed to humans by palm civets ${ }^{24}-$ led to over 8,000 cases by the end of the pandemic (in June 2003). With a mortality rate of close to $9.5 \%$, it brought more attention to $\mathrm{HCoVs}$. Additional HCoVs were identified shortly after that: HCoV-NL63 in $2004^{25}$ and HCoV-HUK1 in $2005^{26}$. As for the endemic $\mathrm{HCOV}-229 \mathrm{E}$ and $\mathrm{HCOV}-\mathrm{OC} 43$, infections with the more recently identified HCoV-NL63 and HCoVHUK1 also resulted in mild and self-limiting diseases. However, they were sometimes associated with severe lower respiratory infections in infants, older adults, or immunocompromised patients. In 2012, MERS-CoV emerged $^{27}$ also as a zoonotic virus that originated in bats, and after a bat to camel switching event may have transferred to humans from dromedary camels. Two MERS-CoV outbreaks caused over 2000 deaths in Saudi Arabia and South Korea, with a mortality rate close to $35 \%$. The elderly and people with underlying morbidities often developed a disease more severe and fatal. The SARS-CoV and MERS-CoV pandemics contributed to recognize the previous knowledge of CoVs' potential as zoonotic agents that can rapidly evolve to cause human pandemics ${ }^{28}$.

\section{Molecular biology of CoVs}

\section{Virus structure and genome organization}

CoVs are classified into four genera: alphacoronavirus, betacoronavirus, gammacoronavirus, and deltacoronavirus, in the Orthocoronavirinae subfamily, Coronaviridae family, and Nidovirales order. They can infect a wide variety of hosts, including avian, murine, bovine, swine, feline, canine, bats, and humans. HCoVs belong either to the alpha- or betacoronavirus genera. The seven HCoVs known today are the alphacoronaviruses, HCoV-229E and HCoV-NL63, and the betacoronaviruses, HCoV-OC43, HCoV-HKU1, SARS-CoV, MERS-CoV, and SARS-CoV-2 (Table 1).

The virions are spherical or pleomorphic enveloped particles with a diameter of $80-120 \mathrm{~nm}$, formed by four or five structural proteins: the spike glycoprotein (S), the 
hemagglutinin-esterase (HE, present in some betacoronaviruses), the membrane glycoprotein (M), the envelope glycoprotein $(E)$, and the nucleocapsid protein $(N)$. The $S$ glycoprotein is a large type I transmembrane polypeptide with an $\mathrm{N}$-terminal exodomain and a $\mathrm{C}$-terminal endodomain. The $\mathrm{S}$ protein assembles into trimeric spikes that protrude from the virus surface with a club-like appearance and mediates receptor binding and membrane fusion. The HE forms shorter dimeric projections and may participate during cell entry and egress. The $\mathrm{M}$ protein is the most abundant virion component and is embedded through three transmembrane domains supporting the viral envelope.

In contrast, the $\mathrm{E}$ protein is a small transmembrane protein present in lower copy numbers. The viral envelope surrounds a nucleocapsid with helical symmetry, which is not characteristic for positive-strand RNA viruses but rather typical of negative-strand RNA viruses. The helical nucleocapsid is formed by the N phosphoprotein, which associates with the RNA genome in a beadson-a-string fashion ${ }^{8}$.

CoVs possess the largest known genomes of RNA viruses, ranging from 27 to $31 \mathrm{~kb}$. Their genome is a non-segmented, single-stranded RNA of positive polarity, modified with a 5'-cap, and 3'-poly(A) tail that can be translated once it enters the cell's cytoplasm. Indeed, the coronavirus genome is infectious when transfected into permissive host cells. The extensive coronavirus genome encodes multiple polypeptides and is organized in a highly conserved 5'-replicase/transcriptase-S-E$\mathrm{M}-\mathrm{N}-3$ ' gene arrangement, with various smaller ORFs interspersed among the S-E-M-N structural genes. The genes that code for the structural proteins occupy less than one-third of the genome at the 3'-end. The remaining two-thirds are occupied by a single gene that codes for the viral replicase/transcriptase proteins. Like other single-stranded RNA viruses, the coronavirus genome has a high mutation rate of about $10^{-4}$ nucleotide substitution/site/year due to an inefficient proof-reading mechanism $^{8}$. Furthermore, CoVs may adapt rapidly to changing ecological niches due to high recombination frequencies that originate from the complex mechanisms responsible for synthesizing various species of viral RNA during genome transcription and replication (Fig. 1).

\section{Coronavirus replication cycle}

\section{Attachment and entry}

Coronavirus binding and entry into the host-cell depend on the $S$ glycoprotein, which is the principal determinant of host species range and tissue tropism. A variety of studies performed through the 1990s demonstrated that swapping of the cellular receptor or the viral $\mathrm{S}$ protein is sufficient to redirect viral tropism and alter the degree of virulence ${ }^{7}$. The $S$ protein comprises two domains: S1 and S2. The interaction between the highly variable S1-RBD domain (receptor binding domain) and the cellular receptor induces a conformational change that promotes membrane fusion between the viral and cellular membranes through the conserved S2 domain. Cell receptors for many CoVs have been identified and, like the S protein, are substantial determinants of pathogenicity, tissue tropism, and host range. The carcinoembryonic antigen-related cell adhesion molecule 1 is a receptor for MHV, whereas the 9-O-acetylated sialic acid is the receptor for $\mathrm{BCoV}$, HCoV-OC43, and HCoV-HKU1. The aminopeptidase-N is the receptor for the transmissible gastroenteritis virus, the porcine respiratory coronavirus, and HCoV 229E. The dipeptidyl peptidase- 4 is MERS-CoV and the angiotensin-converting enzyme 2 (ACE2) is SARS-CoV, HCoV-NL63, and SARS-CoV-2. CoVs enter through cell endocytosis or at the plasma membrane, where other proteases, like furin, the transmembrane protease serine 2 (TMPRSS2), or the airway trypsin-like protease TMPRSS11D may participate in S1/S2 cleavage, facilitating membrane fusion, as in the case of HCoV-229E, SARS-CoV, and SARS-CoV-2 infection ${ }^{20,21 .}$

\section{Viral genome expression and replication}

Upon fusion of the viral envelope membrane to either the plasma or endosome membrane, the viral nucleocapsid is released into the cytoplasm. Subsequently, cellular ribosomes translate the viral genome through a cap-dependent mechanism to synthesize two large polyproteins, pp1a and pp1ab. These polyproteins are encoded in overlapping open reading frames ORF1a and ORF1b that are translated through a ribosomal frameshift mechanism in which the ribosome shifts one nucleotide in the -1 reading frame of ORF1a into the ORF1b frame. The resulting pp1a and pp1ab are cotranslationally and autoproteolytically processed to produce 15 or 16 nonstructural proteins (nsp) (Table 2). Nsp1 to nsp11 are generated from pp1a and nsp12 to nsp16 from pp1ab. Nsp encoded in the ORF1a and 1ab genes form the replicase/transcriptase complex (RTC) that transcribes the full-length positive-strand genomic RNA to direct the synthesis of a full-length negative-strand RNA that functions as a template for the synthesis of new genomic RNA. The RTC assembles 


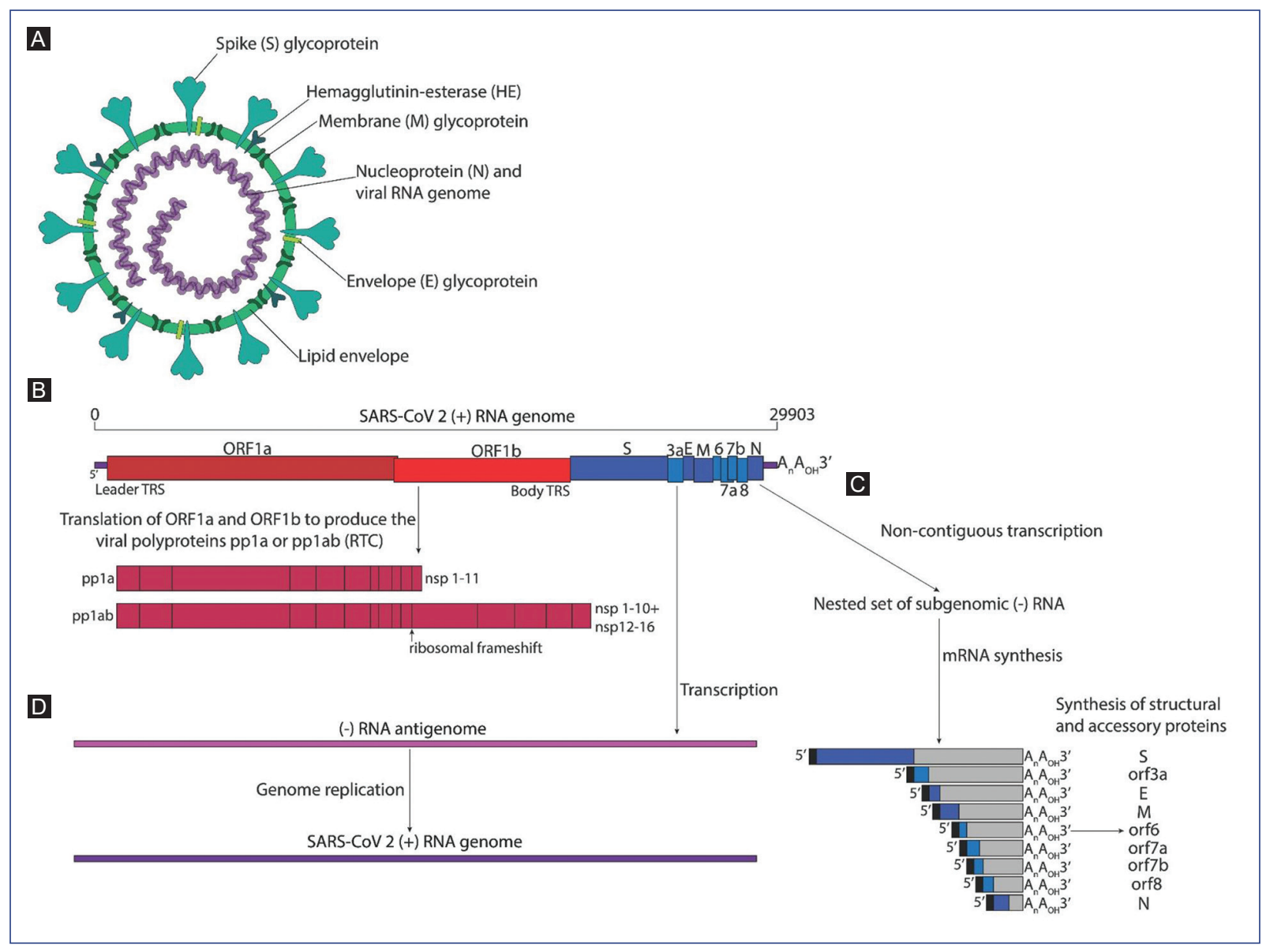

Figure 1. Diagram of the coronavirus virion, genome organization, polyprotein processing, subgenomic RNA production, and genome replication. A: The virion consists of the helical nucleocapsid formed by the N protein-associated RNA genome, surrounded by a lipid envelope where the M, S, E (and HE in some betacoronaviruses) transmembrane glycoproteins are embedded. B: The positive-strand RNA genome is organized with the Orf1a and Orf1b occupying nearly two thirds of the $5^{\prime}$ end of the genome, which are translated to produce the autoproteolitically processed pp1a and pp1ab polyproteins, respectively, yielding nsp1 to nsp16 (shown in different shades of red). The remaining one third $3^{\prime}$ end of the genome encodes the S, E, M, N structural and the accessory proteins (shown in different shades of blue). C: The mRNAs that encode the structural and accessory proteins are produced through the non-contiguous-nestedtranscription of negative-strand subgenomic RNAs that direct the synthesis of their corresponding complementary mRNAs, which share common $5^{\prime}$ and $3^{\prime}$ ends. Only the $5^{\prime}$ most ORF is translated from each nested mRNA (shown in boxes with different shades of blue). D: The full-length positive strand RNA genome is transcribed to produce a fulllength negative-strand antigenomic RNA that serves as the template for the synthesis of the positive-strand RNA during genome replication.

in a reticulovesicular network of modified ER membrane induced in the infected cell, where viral RNA replication takes place. The new genomic RNA molecules are encapsidated and incorporated into progeny virions on membranes of the endoplasmic reticulum-Golgi intermediate compartment (ERGIC) 20-22.

\section{Polyprotein processing}

As in other positive-strand RNA viruses, coronavirus polyproteins' proteolytic cleavage is a crucial process for regulated viral gene expression. However, in CoVs, polyprotein processing implicates multiple cleavage sites that produce many enzymes involved in coronavirus RNA synthesis and modification that is unique in RNA viruses. Such complex proteolytic processing depends on the "main" protease $\left(\mathrm{M}_{\text {pro }}\right)$-a chymotrypsin-like (picornavirus $3 \mathrm{C}$-like) cysteine protease $\left(3 \mathrm{CL}_{\text {pro }}\right)$ that resides in $\mathrm{nsp} 5$ and cleaves at 11 sites to generate 13 polypeptides (nsp4-nsp16)-and on one or two accessory papain-like cysteine proteases (PL1pro and PL2pro) that reside in nsp3 and process 
Table 2. Functions of coronavirus nonstructural proteins

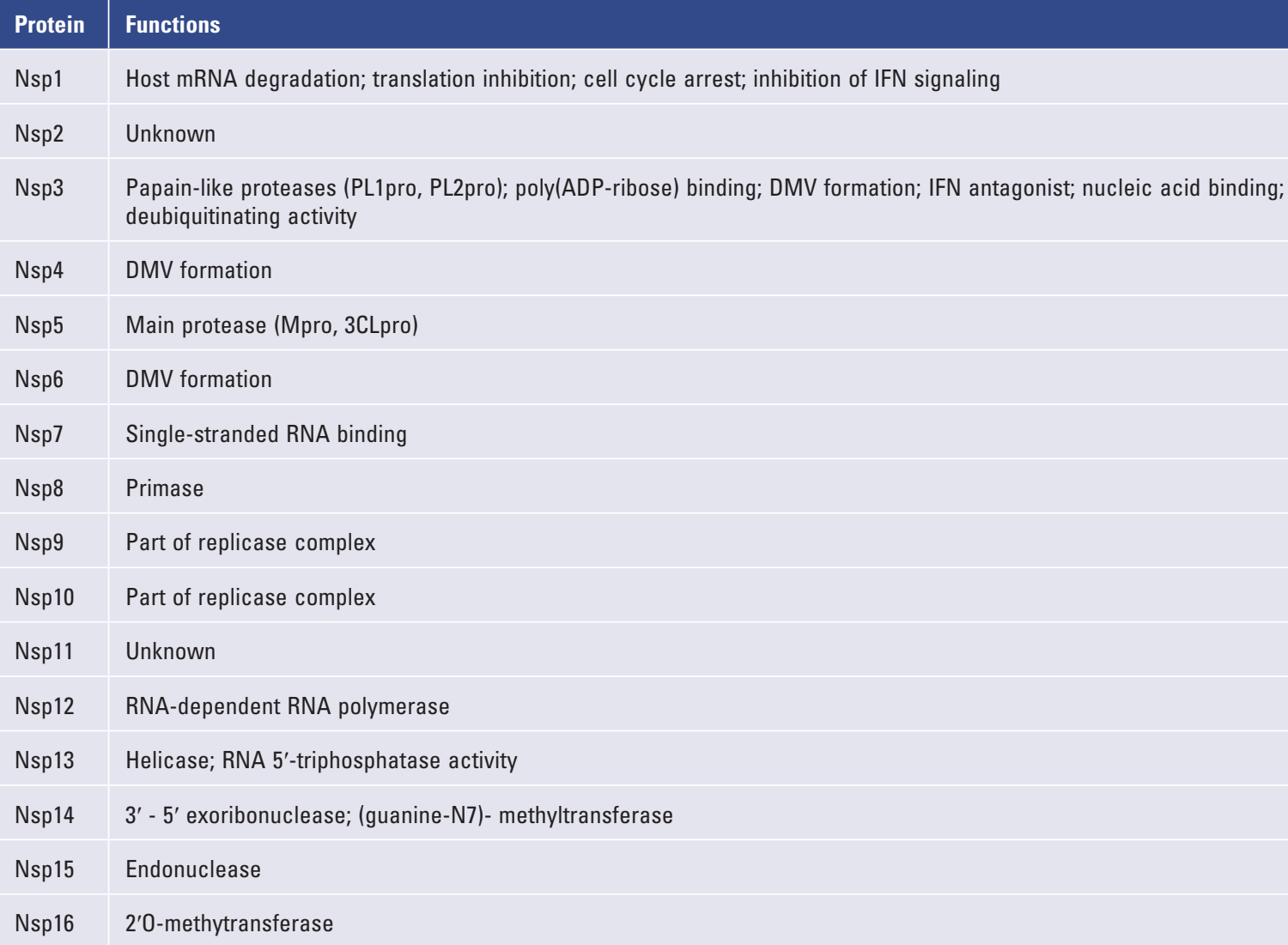

DMV: double-membrane vesicle; IFN: interferon; RNA: ribonucleic acid.

nsp1-nsp4, the C-terminus of nsp4 being cleaved by the $M_{\text {pro }}$.

Some of the 16 nsp functions produced after polyprotein cleavage are summarized in table 2 . These include the core viral enzymes responsible for RNA synthesis during viral genome transcription and replication: the RNA-dependent RNA polymerase (nsp12), the RNA polymerase primase (nsp8), the RNA helicase (nsp13), and the 3'-5' exoribonuclease (nsp14), as well as other RNA processing enzymes, such as poly $(U)$ endoribonuclease, cyclic phosphodiesterase, and adenosine diphosphate-ribose-phosphatase. Additional enzymes include those required for 5' capping of viral RNAs through the (guanine-N7)-methyltransferase activity of the bifunctional nsp14 and nsp16 S-adenosyl-methionine-dependent RNA (nucleoside-2'O)-methyltransferase (2'O-MTase) activity, which may function together with nsp $15^{29}$.

\section{Viral genome transcription}

After production and processing of viral polyproteins, the RTC is assembled to direct transcription of the genes that occupy the remaining one-third of the genome near the 3 '-end that is not directly translated from the positive-strand RNA genome and encodes the structural proteins (S-E-M-N), and 1 to 8 additional accessory proteins ${ }^{20}$. These genes are transcribed through a mechanism unique to the Nidovirales order, involving non-contiguous transcription of the 3 '-end of the viral genome-where the viral RNA-dependent RNA polymerase (RdRp) skips from one part of the genome to the next to generate a nested set of subgenomic negative-strand RNAs. The subgenomic RNAs contain common 3 '-ends and a common leader encoded at the 5'-end of the genomic RNA. Transcription termination and acquisition of the leader 5' RNA occur at transcription regulatory sequences located between ORFs. These negative-strand subgenomic RNAs serve as templates for synthesizing subgenomic mRNAs with common 5' leader and 3' sequences. Translation of these mRNAs produces proteins only from the ORF closest to the 5 ' leader on each of the nested mRNAs ${ }^{8}$. 


\section{Replication compartments}

RTC associates with ER-derived membranes (remodeled by nsp3, nsp4, and nsp6) to form a pervasive network of convoluted membranes (CM), double-membrane vesicles (DMV), and vesicle packets (VP), where viral proteins and RNA are compartmentalized. Electron tomography revealed that the membrane network is continuous with the ER and contains large vesicles with abundant viral dsRNA and that they are not connected to the cytoplasm. Analysis at late stages of infection suggests that the membrane network involved in virus replication may merge with membranes where virus assembly occurs ${ }^{30}$. These virus-induced membrane compartments represent replication organelles (RO), where viral genome transcription and replication seem to be orchestrated. The nsp3, nsp4, and nsp6 are transmembrane proteins that anchor the RTC to induce the formation of structures that provide a scaffold responsible for viral RNA synthesis and protection of the RNA intermediates from cellular antiviral mechanisms ${ }^{8}$. The crucial steps of virus subgenomic and genomic RNA and mRNA synthesis are controlled at these sites and implicate dynamic interactions of nsps, viral RNAs, and the $\mathrm{N}$ protein. The subgenomic RNA (produced at these sites) directs the synthesis of structural proteins, while the recruitment of $\mathrm{N}$ protein oligomers through association with nsp3 may promote the assembly of ribonucleoprotein complexes ${ }^{31}$.

\section{Virus assembly}

The $S, M, H E$, and $E$ proteins are synthesized in association with the ER. These proteins transit to the ERGIC, where nucleocapsids assembled by the $\mathrm{N}$ protein and newly produced genomic RNAs are encountered. Virion assembly proceeds through interactions among the structural proteins, where the $M$ protein plays a central role. Interestingly the M protein and the minor $E$ protein were shown to be necessary and sufficient for the formation of virus-like particles (VLPS). VLPs, devoid of $S$ spikes, are morphologically similar to virions and are released from cells through the same pathway as complete virions. During infection, the interaction between $\mathrm{M}$ and $\mathrm{N}$ proteins directs nucleocapsid and membrane components assembly when packaging signal sequences selectively package the genomic RNA, leading to the formation of virions transported to the plasma membrane and released by exocytosis ${ }^{7}$ (Fig. 2).

\section{Virus-host interactions}

\section{Virus-induced alteration of the infected host cell}

Viruses are obligate intracellular parasites that depend on the cellular architecture and functions for their replication. Upon infection, viruses may induce extensive cell structure reorganization resulting in cytopathic effects due to cell membrane or cytoskeleton components' alterations. In addition, viruses may target several physiological and biochemical aspects of cells by inducing changes in signaling pathways, cellular gene expression, regulation of synthesis of cellular macromolecules, and alterations in the overall cellular metabolism, resulting in enhanced viral replication ${ }^{32,33}$.

The concentration and compartmentalization of macromolecules needed for viral genome replication and gene expression are induced during viral replication, resulting in specialized virus-induced cellular microenvironments termed viral factories, viroplasms, replication centers, compartments, or organelles. Such RO also represents a physical barrier that protects the viral genome from cellular defenses ${ }^{34-37}$.

As mentioned before, CoV-replication is accompanied by a variety of intracellular membrane rearrangements derived from the ER, resulting in the formation of ROs that display various discernible morphologies such as DMVs, which range from 150 to $350 \mathrm{~nm}$ in diameter, and are sites where viral dsRNA replication intermediates accumulate. DMV may fuse to form larger structures called VP. DMVs are interconnected with convoluted reticular membranes (CMs), which range from 0.2 to $2 \mu \mathrm{m}$ in diameter and are the primary sites where viral replicase proteins are colocalized. At late times post-infection, structures known as large virion-containing vesicles are formed, enriched with viral structural proteins ${ }^{38-40}$. The nsp3, nsp4, and nsp6 are integral membrane replicase proteins that promote ROs assembly by inducing membrane remodeling and recruitment of factors necessary for viral genome transcription and replication. The sole expression of nsp3 and nsp4 is sufficient to induce membrane curvature ${ }^{41}$. Nsp3 is a large multifunctional protein comprising up to sixteen different domainsthought to function as a scaffold for RO assembly and regulation of $\mathrm{RO}$-associated activities through its interaction with several proteins that participate in replicating and transcribing the viral genome. For example, the ubiquitin-like (ubl) domain of nsp3 is involved in ssRNA-binding and interaction with the viral nucleocapsid $\mathrm{N}$ protein. Interaction of nsp3 with $\mathrm{N}$ tethers the viral RNA to the 


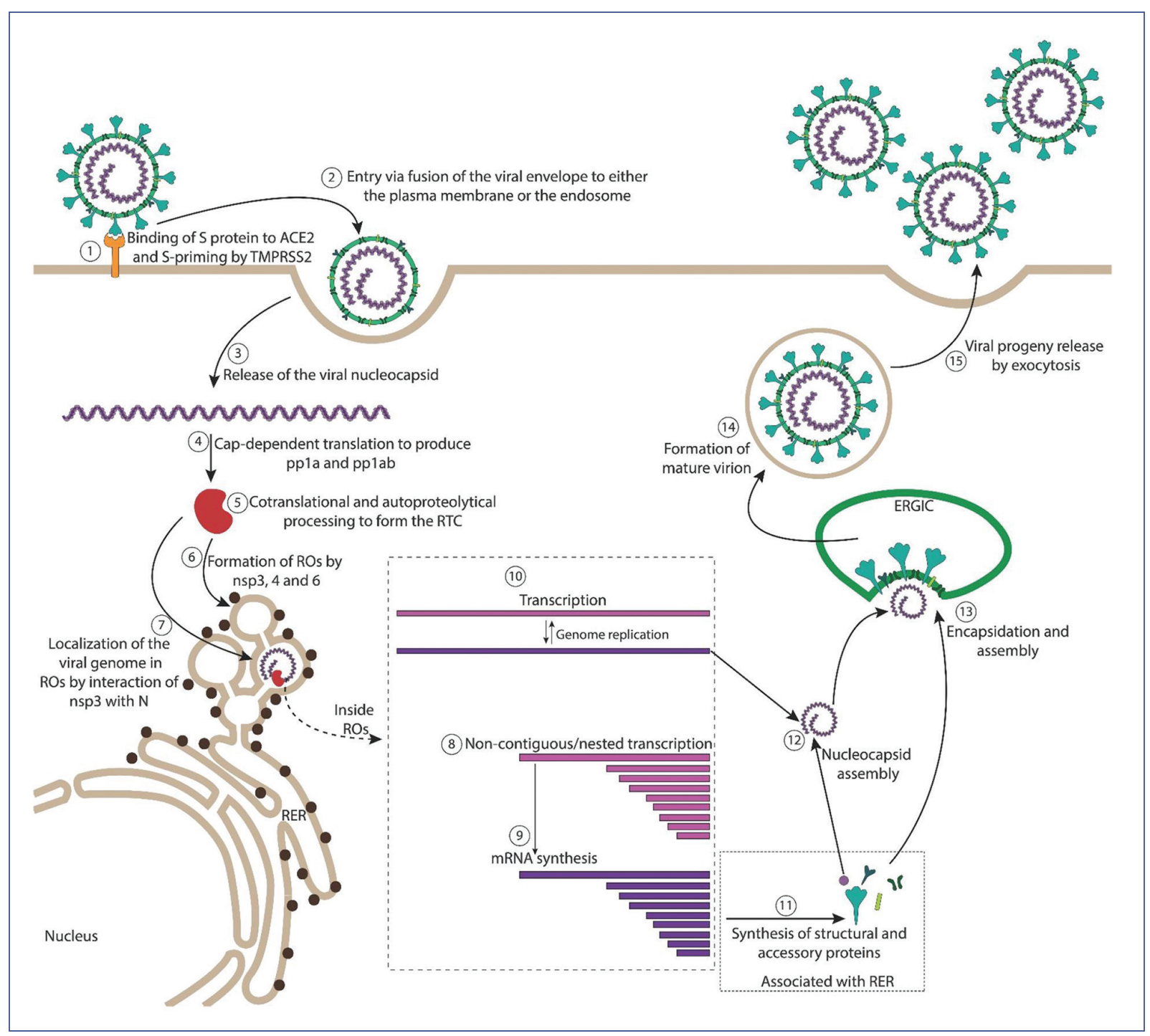

Figure 2. Coronavirus replication cycle. (1) The coronavirus virion binds to the cellular receptor and (2) enters the cell through fusion of the viral envelope either with the plasma membrane or the endosome. (3) The nucleocapsid is released into the cytoplasm, where (4) cellular ribosomes translate the $5^{\prime}$ end of the genome through a cap-dependent mechanism to produce the pp1a and pp1ab polyproteins that are (5) cotranslationally autoproteolytically processed that yield the nonstructural proteins (nsps 1-16) that form the replicase/transcriptase complex (RTC), and other proteins that alter many cell functions. (6) The nsp3, 4, and 6 participate in formation of virus-induced replication organelles (R0s), where (7) the viral genome localizes and (8) non-contiguous transcription of the $3^{\prime}$ end of the genome produces the nested subgenomic RNAs that are (9) transcribed into the mRNAs that encode the viral structural S, E, M, N proteins. (10) The full-length positive-strand RNA is also transcribed in these sites producing the full-length negative-strand RNA that serves as the template for viral genome replication. (11) The mRNAs that encode the structural proteins are translated by ribosomes that associate with the ER and are translocated, glycosylated, and processed through ER and Golgi. (12) Association of the N protein with newly synthesized viral RNA genomes forms the nucleocapsid that interacts with the (13) ERGIC membranes acquiring the S, M, E proteins, leading to (14) formation of the mature virion that is released from the cell (15) through exocytic vesicles.

RTC in ROs early during infection, and deletions within the ubl domain result in impaired viral RNA replication ${ }^{42}$. Several other viral proteins are known to be part of ROs, including the nsp2, 5, 7-10, and nsp12-16 and the $\mathrm{N}$ protein, together with cellular proteins that participate in vesicular trafficking, ubiquitin-dependent, and autophagy-related proteins and translation factors that localize at the cytoplasmic face of $\mathrm{ROs}^{43}$. 


\section{Innate antiviral response}

It was mentioned earlier that ROs are thought to shield the viral RNA and proteins from recognition by the host antiviral mechanisms, as viral RNA and replicase subunits become sensitive to nuclease or protease treatment only after membrane disruption by non-ionic detergents ${ }^{44}$. Therefore, the formation of ROs is a crucial mechanism for evasion of the cellular antiviral response. Although the specific antiviral mechanisms altered or inhibited by SARS-CoV-2 through reorganization of intracellular membranes and redistribution of cellular components have not been studied in detail, evidence indicates that some CoV proteins induce intracellular stress pathways, which are known to crosstalk with the immune response ${ }^{45}$. Since HCoVreplication takes place in ROs that are assembled by remodeling of ER membranes, it is expected that the alterations of the ER lead to the activation of the unfolded protein response (UPR). This stress-induced signaling pathway leads to inhibition of translation while increasing the synthesis of ER membranes and chaperones needed to counteract the accumulation of misfolded or unfolded proteins. Expression of the viral structural S protein correlates with transcriptional activation of the glucose-regulated protein 78 and 94 (GRP78/94) and upregulation of the PKR-like ER kinase (PERK) pathway from the UPR and induce the innate immune response by inducing the expression of the chemokine CXCL2 ${ }^{46,47}$. The viral accessory protein ORF9a is a transmembrane protein that localizes to the ER and is also a modulator of the ER stress response, modulating the PERK pathway and resulting in the phosphorylation, ubiquitination, and degradation of the interferon (IFN)-alpha receptor subunit $1^{48}$. ORF8b forms intracellular aggregates, induces ER and lysosomal stress, and causes cell death in epithelial cells. This viral protein induces the activation of the intracellular sensor NOD-, LRR-, and pyrin domain-containing protein 3 (NLRP3) and release of the pro-inflammatory cytokine IL-1 $\beta$, which may trigger aberrant activation of pro-inflammatory monocyte-macrophages ${ }^{49}$. The activation of the PERK pathway subsequently leads to phosphorylation of the translation-initiation factor elF2 $\alpha$ and, therefore, translation shutoff 50 .

More than 7 months have elapsed since the discovery of SARS-CoV-2, which may seem a long time for the lockdown, but represents a relatively short time for an exhaustive study of the immune response's development and evolution against this virus in a human population. As a result, many of the studies reported to date are either clinical case studies or studies with small groups of patients that have presented severe symptoms or symptoms considered atypical. However, some key aspects of cellular antiviral mechanisms and viral countermeasures have been described. Given the similarity between SARS-CoV-2 and SARS-CoV and the conserved mechanisms of the innate antiviral response, detection of SARS-CoV-2 by intracellular receptors is likely mediated by Toll-like receptors and RIG-I-like receptors. These receptors trigger downstream signaling and activation of transcription factors, such as IFN-regulatory factors (IRFs) and nuclear factor kappa $\mathrm{B}$ (NFKB), which result in the expression of IFN response genes and other cytokine genes ${ }^{51,52}$.

The genome of SARS-CoV-2 also encodes proteins that counteract the antiviral activity of specific intracellular immune receptors. The structural $\mathrm{N}$ protein of SARS-CoV-2 inhibits the type I IFN response ${ }^{53}$. It is also suggested that the nonstructural viral protein nsp3 is a type I IFN antagonist ${ }^{20}$ that promotes $\mathrm{RO}$ assembly. Nsp9 targets MIB1, an E3 ubiquitin ligase that promotes TNF-induced apoptosis. Nsp13 targets TBK1, TBKBP1, and the NFKB pathway.

Moreover, the nsp15 endonuclease (EndoU) that is highly conserved among CoVs targets RNF41 (an E3 ubiquitin-ligase for MYD88) and prevents activation of MDA5, OAS/RNase L, and PKR ${ }^{54,55}$. In addition, viral accessory proteins can block innate immune factors: ORF9b targets TOMM70, the mitochondrial import receptor that mediates activation of IRF3 in mitochondria ${ }^{56}$. ORF9c targets NLRX1 (a negative regulator of IFN-I), F2RL1 (modulator of the inflammatory responses and innate and adaptive immunity), and NDFIP2 (a factor that limits cytokine signaling by promoting degradation of JAK1 by NEDD4-mediated ubiquitination). ORF3a targets TRIM59 (a regulator for innate signaling pathway), and the ORF6 protein blocks the IFN-inducible mRNA nuclear export complex NUP98RAE1, therefore altering the transport between the nucleus and the cytoplasm ${ }^{57}$. All of these SARS-CoV-2 - cellular protein-protein interactions lead to an impaired antiviral response, with inefficient production of type I IFN and increased cell death, which is linked to severe outcomes of COVID-19 that results from hyper inflammation and the cytokine storm ${ }^{51,58}$. In contrast to mild HCoVs infection ${ }^{22}$, serum samples from severe COVID19 patients are characterized by low levels of IFN and elevated levels of chemokines and pro-inflammatory cytokines that result in peripherally derived macrophages in the lungs and an influx of activated neutrophils ${ }^{59,60}$. 


\section{Adaptive immune response}

There is increasing evidence suggesting that exposure to SARS-CoV-2 infection generates a good adaptive immune response, both cellular and humoral, which are encouraging results for a good prognosis for protection against reinfection and vaccine development. However, this response appears to be more efficient for patients with severe COVID-19 than for asymptomatic or mildly symptomatic patients ${ }^{61}$.

Together with IgMs, immunoglobulins $A$ in mucosal membranes are the first antibodies generated against invading agents and can be observed since the first week of infection. IgGs against SARS-CoV-2 are usually detected between 10 days and 2 weeks after the onset of symptoms. These immunoglobulins and complement proteins are produced at expected levels to confer protection; however, their duration has yet to be determined ${ }^{62}$.

Other findings suggest that SARS-CoV-2 could evade immune surveillance through a hidden RBD of the spike protein, which is not well recognized by immune factors compared to an exposed RBD ${ }^{63}$. Although virus-cell recognition may be generally established through the interaction between viral structural proteins and cell surface receptors, cells that do not express virus receptors may be infected by antibody-dependent enhancement (ADE). It has been suggested that $A D E$ could be promoted by the presence of non-neutralizing or sub-neutralizing antibodies against the S-protein ${ }^{64}$. Similar to what has been reported for SARS-CoV, this mechanism could aid SARS-CoV-2 to infect immune cells lacking ACE2 expression by binding to Fcy receptors for cell entry ${ }^{65}$. Nonetheless, whether SARS-CoV2-infection can be mediated by ADE or infect immune cells remains unknown ${ }^{6}$.

In addition to humoral immunity, protection against different pathogens is mediated by T-lymphocytes, which may confer long-term immunity ${ }^{67}$. A T-cell response is more likely to be induced by the nsp. However, there is evidence that the $S$ protein can also induce memory T-cell differentiation, as measured by S-RBD-specific T cell production of IFN $\gamma^{68}$. CD4+ cells mainly differentiate toward memory Th1 and Th17 helper cells, and there is also evidence for the development of cytotoxic CD8+ cells against SARS-CoV-2 infected cells ${ }^{60}$. Some studies have shown that the number and activity of CD8+ cells are higher than the response of CD4+ cells ${ }^{69,70}$.

A good observation has been discovering cross-reactivity both for cellular and humoral responses, possibly with other endemic HCoVs or with SARS-CoV, which is likely because nsps of SARS-CoV-2 share high sequence identity with other $\mathrm{HCoVs}$. A recent report has shown the presence of $C D 4+T$ cells that recognize a panel of SARS-CoV-2 - specific peptides in $40-60 \%$ of unexposed individuals (samples collected between 2015 and 2018) ${ }^{71}$. In addition, cross-immunity has also been observed with humoral response against the $S$ protein, although most of the cross-reactive antibodies are non-neutralizing ${ }^{72}$.

An interesting observation is the low incidence of severe COVID-19 cases in children. Analysis of human memory $B$ cells (MBC) at different ages has shown that CD27dull and CD27bright represent sequential MBCdevelopmental stages, leading to the proposal that CD27dull MBCs can expand and differentiate in response to new antigens. Based on these findings, Carsetti et al. proposed that the protective action of non-antigen specific natural antibodies (NAbs) produced by CD27dull MBCs, which are more abundant in children than in adults, could be a determining factor; however, this hypothesis remains to be confirmed ${ }^{73,74}$.

Severe COVID-19 patients may develop lymphopenia (with depletion of CD4+ and CD8+ cells), which could be induced through signaling exhaustion through inactivation of cytotoxic lymphocytes by IL-6 and IL-8 or viral-mediated apoptosis. In Wuhan, RNA obtained from bronchoalveolar lavage fluids (BALF) and peripheral blood mononuclear cells (PBMC) from SARS-CoV-2 patients indicated an increase in the expression of pro-apoptotic genes and p53-targets, suggesting that lymphopenia may be caused by activation of the p53 signaling pathway and induction of apoptosis in lymphocytes $^{75}$. One of the viral components responsible for apoptosis induction could be the accessory protein ORF3a, which is known to induce apoptosis ${ }^{76}$. Recently, it was shown that cells expressing SARS-CoV-2 ORF3a displayed increased annexin $\mathrm{V}$ and propidium iodide cell staining, as well as increased activation of caspases, cytochrome $\mathrm{C}$ release from mitochondria, and other apoptotic markers ${ }^{77}$.

\section{Pathogenesis}

\section{Clinical manifestations}

As previously described above, infection with the SARS-CoV-2 results in a respiratory illness that has been named COVID-19. Most infected people are either asymptomatic or manifest mild symptoms such as fever, headaches, cough, dyspnea, loss of taste and 
smell, and myalgia or fatigue ${ }^{78}$. The average person takes 5-6 days after infection for symptoms to show, but in some rare cases, symptoms appear after up to 14 days $^{79}$. In more severe cases, the disease causes pneumonia and ARDS. The global infection fatality rate (IFR) is estimated to be around $0.68 \%$, according to a recent meta-analysis ${ }^{80}$, but the specific IFR varies depending on the country. Males are predominantly affected and represent about $60 \%$ of the total death cases due to COVID-19. People with comorbidities such as obesity, diabetes, and hypertension also have a higher probability of severe disease or a lethal outcome. After 7 months since the start of the pandemic, with the rapid spread of the virus and increased patients with severe cases, it has become evident to clinicians that COVID-19 also has several extrapulmonary manifestations. Despite a seemingly protective effect against COVID-19, rare symptoms in pediatric patients have emerged in the case of children. It is now apparent that COVID-19 is not just a pulmonary disease but one with pulmonary-hematological-endothelial-inflammatory consequences.

\section{RESPIRATORY}

SARS-CoV-2 is transmitted through respiratory droplets and aerosols, direct or indirect respiratory-tract exposure, and potentially by the fecal-oral route ${ }^{81,82}$. It has a high tropism for the respiratory tract epithelial cells where there is increased expression of its entry receptor, ACE2, including alveolar epithelial type II cells in the lung parenchyma ${ }^{83}$. Viral replication is understood to first occur in the upper respiratory tract and then further infect and replicate in the lower respiratory tract. In contrast to SARS-CoV, which infects mainly the lower respiratory tract, SARS-CoV-2 can activate replication in the upper respiratory tissues ${ }^{84}$, explaining the virus continuous high pharyngeal shedding, even in asymptomatic cases ${ }^{61}$, resulting in the more efficient transmission of SARS-CoV-2 compared to SARS-CoV. Asymptomatic and pre-symptomatic transmission is estimated to account for around half of all cases of COVID-1985.

SARS-CoV-2 replication in the lungs can manifest as ARDS in severe cases of COVID-1978. ARDS is a life-threatening lung condition that prevents oxygen from getting to the lungs and into the circulation in the bloodstream, resulting in death or acute lung injury. This later stage in severe cases of COVID-19 resembles SARS-CoV and MERS-CoV infections in terms of viral replication in the lower respiratory tract ${ }^{86,87}$. The disease can cause a secondary viremia, followed by an extensive infection of organs that express the viral entry receptor ACE2 such as the heart, kidney, GI tract, and vast distal vasculature ${ }^{88-90}$. The spread of the virus, which occurs on average around week 2 after disease onset, correlates with clinical deterioration. However, the exacerbation of the disease resulting in organ dysfunction and death is attributed to direct viral organ damage and a consequence of immune-mediated injury induced by SARS-CoV- ${ }^{88}$. Two distinctive features have been observed in severe and critical patients with COVID-19: a progressive increase of inflammation and a notable hypercoagulation trend.

\section{Gastrointestinal}

One of the most commonly reported extrapulmonary manifestations of COVID-19 are GI symptoms, which have been associated with a longer duration of illness, but no association with increased mortality ${ }^{91}$. The most common symptoms are anorexia, nausea, vomiting, diarrhea, and abdominal pain ${ }^{91,92}$. Symptoms such as vomiting and diarrhea were often reported during the SARS-CoV and MERS-CoV outbreaks, and more frequently than for COVID-1993-96. Most COVID-19 patients show Gl symptoms after respiratory symptoms, although they have also been reported earlier but less frequently ${ }^{95}$. Intestinal glandular cells express the ACE2 receptor; thus, virus-mediated direct damage is a possibility. The SARS-CoV-2 nucleocapsid protein has been found in gastric, duodenal, and rectal epithelial cells, as well as in glandular enterocytes ${ }^{97}$. Furthermore, viral RNA shedding in stool has been reported to occur during infection. In some cases, it is detected several days after symptom resolution; therefore, it is thought to be a possible source of viral transmission ${ }^{81,97}$. In COVID19 patients, evidence suggests microvascular smallbowel injury and evidence supporting inflammation-mediated tissue damage in the stomach, duodenum, and rectum ${ }^{91,97}$.

\section{Neurological}

The most common symptoms linked to neurological damage in mild cases of COVID-19 are headache, dizziness, myalgia, fatigue, anorexia, anosmia, and ageusia. Nasal epithelial cells have the highest expression levels of ACE2 in the respiratory tract ${ }^{83,98}$, which could explain the reported loss of smell and taste in many infected people. Severe neurological manifestations are not as common as other extrapulmonary 
manifestations of COVID-19; however, reports are rapidly increasing. In more severe cases, symptoms such as confusion, impaired consciousness, and acute strokes can occur ${ }^{99,100}$. A few patients have developed Guillain-Barré syndrome ${ }^{101,102}$, meningoencephalitis $^{103,104}$, hemorrhagic posterior reversible encephalopathy syndrome $\mathrm{e}^{105}$, and acute necrotizing encephalopathy (which is related to intracranial cytokine storm) that included the brainstem and basal ganglia ${ }^{104,106}$. In a few of these COVID-19 patients, the virus has been detected in the cerebrospinal fluid. SARS-CoV and MERS-CoV (and other CoVs) are known to have neuroinvasive potential since they can spread from the respiratory tract to the central nervous system $(\mathrm{CNS})^{107-109}$. It is proposed that the virus could access the brain through circulation or an upper nasal transcribrial route ${ }^{110}$. This neuroinvasive capability of SARS-CoV-2 could damage the CNS by misdirecting the host immune responses, which could be associated with autoimmunity and viral replication induced damage to CNS cells.

\section{Coagulopathies}

At the beginning of the SARS-CoV-2 outbreak, most of the lung damage seen initially in COVID-19 patients was thought to be due to acute viral pneumonia. However, thrombotic complications and severe inflammation have been reported in critical COVID-19 patients. The first reports of clotting disorders were observed in February in China, where the frequent observation of thrombocytopenia, prolonged thrombin time, and elevated D-dimer levels was reported in severe COVID-19 patients ${ }^{111,112}$. The data suggested disseminated intravascular coagulation (DIC) or pre-DIC. Studies from the Netherlands and France later showed a $30 \%$ incidence of thrombotic complications in intensive care unit patients with COVID-19. Among the observed thrombotic complications, pulmonary embolism was the most frequent $(80 \%)$; however, deep-vein thrombosis, ischemic stroke, myocardial infarction, and systemic arterial embolism were also reported ${ }^{113,114}$. Systemic anticoagulation (AC) treatment has been used in critical patients to improve their outcomes. However, a debate over the appropriate dosage (standard vs. high doses) of $\mathrm{AC}$ is still ongoing. Therefore, clinical trials like IMPROVE-COVID from Columbia University have started to assess the effectiveness of AC treatments and their dosage ${ }^{115}$. Coagulation disorders have also been previously reported for several SARSCoV cases; thrombocytopenia was also frequent in MERS-CoV patients, although data are less available ${ }^{116}$. Interestingly, SARS-CoV has been shown to upregulate procoagulant genes and genes associated with the coagulation pathway in vitro ${ }^{117,118}$. SARS-CoV nucleocapsid protein has also been shown to induce the human fibrinogen-like protein-2 prothrombinase gene through activation of the transcription factor C/EBP- $\alpha^{119}$. Furthermore, transgenic mouse models infected with MERS-CoV activate coagulation cascades and form microthrombi in pulmonary vasculature ${ }^{120}$.

Clot formation is thought to occur for three reasons:

1) Due to the direct infection of endothelial cells by SARS-CoV-2. Endothelial cells express ACE2, and both SARS-CoV-2 and SARS-CoV-2 can infect engineered human blood vessel organoids in vitro and have been detected in vascular beds of different organs in patients with COVID-1990,121,122. Viral replication can cause alveolar endothelial dysfunction, platelet activation, generation of neutrophil-platelet aggregates, neutrophil migration, and fibrin and microthrombus formation. When uncontrolled, these alterations would trigger secondary fibrinolysis, coagulation factors depletion, and consequently DIC and diffuse alveolar hemorrhage ${ }^{112}$.

2) Inflammation during severe cases of COVID-19 can promote coagulation. Recruitment of immune cells by a direct viral infection of endothelial cells or by pro-inflammatory signaling can cause widespread endothelial dysfunction, inflammation, and a procoagulant state. Accumulation of inflammatory cells within the endothelium and cell death has been observed in severe COVID-19 patients, suggesting endotheliitis in several organs as a consequence of SARS-CoV- $2^{90}$. Complement components in the lung and skin, colocalizing with SARS-CoV-2 proteins, have also been reported, suggesting complement-mediated thrombotic microvascular injury syndrome ${ }^{123}$.

3)Other factors not specific to SARS-CoV-2 infection could also be involved, such as patients with high clotting risk factors, like in older adults; obese or overweight patients, and those with diabetes or high blood pressure. A state of hypoxia and long periods of immobilization in critical patients could also contribute to clotting.

\section{COVID-19 in children}

Pediatric COVID-19 cases have been estimated to account for only $1-5 \%$ of the confirmed cases ${ }^{124}$. The severity and the mortality of the disease among children is significantly lower ${ }^{125}$, causing only mild symptoms such as fever and coughing in most cases and dyspnea in a few cases. Neonates have a nonspecific 
presentation with fever and lethargy. Most hospitalized children with severe COVID-19 have been associated with other underlying conditions ${ }^{124}$. Therefore, it has been suggested that age has a possible protective effect, one which may hold the key to find therapeutic targets. Two main theories that could operate in combination are thought to explain the protective effect of age: (1) the differences in pediatric immune responses compared to adults ${ }^{74}$, and (2) the differences in the availability of viral binding sites necessary for viral entry in airway epithelial cells ${ }^{126,127}$. As previously discussed, extensive lung damage and other extrapulmonary manifestations of severe COVID-19 that complicate adult cases are thought to be a consequence of an overactive immune response and not directly related to viral replication. In comparison, children's immune system is thought to respond less aggressively to SARS-CoV-2 infection. An imbalance in the production of pro- versus anti-inflammatory cytokines may contribute to this process. An example would be the declining production of IL-10 levels with age, which plays an anti-inflammatory role as it decreases macrophage activation and the release of inflammatory cytokines such as IL- 6 , TNF- $\alpha$, and IL-1 $\beta$. Murine models for lung injury have shown a larger increase in neutrophil infiltration and IL-1 $\beta$ levels in adult mice - which have lower levels of IL-10 and IL-13 - but not in young mice ${ }^{128,129}$. Furthermore, it has been proposed that children's IgM B cells (MBCs) can produce NAbs rapidly and abundantly before producing high-affinity IgG antibodies, which would help during the early phases of infection ${ }^{130,131}$. In this context, since CD27dull MBCs are proposed to respond to new antigens, conferring children a highly adaptable response to new antigens, children's NAbs would have broader reactivity as they have not yet been selected for reaction to common environmental pathogens ${ }^{74}$. Another immune difference between children and adults is CD8+ and CD4+ lymphocyte levels. Children before 3 years of age have higher CD4+ cells than adults, and levels of CD8+ cells are slightly increased in elderly adults $^{132}$. Lymphocytopenia has been reported frequently as a risk factor for most adult COVID-19 patients. It has been proposed that differences in the CD4+/CD8+ ratios between children and adults have a protective effect on children, but it has not been confirmed yet ${ }^{127}$. Differences between children and adults have also been observed in the availability of SARS-CoV-2 cellular receptors (ACE2 and TMPRSS2) in lung epithelial cells. Transcriptomic data from lung cells across the age span of 30 weeks, 3 years, and 30 years show an increase in the proportion of alveolar epithelial cells expressing ACE2 and TMPRSS2 in adult lungs compared with young lungs ${ }^{133}$. Furthermore, cell-specific expression analysis of viral entry mediators found that ACE2 and TMPRSS2 expression in airway epithelial and alveolar type 2 (AT2) cells increases with age, with deficient expression in infants and young children ${ }^{134}$. These data may suggest less available viral entry points in the lung epithelial cells in children compared to adults. Furthermore, a recent Gene Set Enrichment Analysis showed that high expression of ACE2 was also related to the activation of neutrophils, NK cells, Th17 cells, Th2 cells, Th1 cells, dendritic cells, and TNF- $\alpha$-secreting cells, which could lead to a more severe inflammatory response ${ }^{135}$.

It is still unknown to what extent children transmit SARS-CoV-2. This understanding is of great importance for all countries to ensure safe reopening measures for schools. The sum of a few small epidemiological studies with children, with a few dozen cases, concludes that they are not the transmission source. Rather they might acquire the virus from adults in the great majority of cases $^{136}$. However, larger pediatric cohorts are needed to determine the incidence of SARS-CoV-2 in children. For example, the Human Epidemiology and Response to SARS-CoV-2 from the NIH; the Pediatric Tuberculosis Network European Trials Group; the Kids Corona from Sant Joan de Déu (SJD) Barcelona Children's Hospital, among others, where they are following kids and their families for several weeks, and in summer camps, to determine pediatric transmission ${ }^{115,125,137}$. Preliminary results of the home transmissibility study from the SJD Children's Hospital, where 724 children living with a COVID-19 positive parent were monitored, showed that the percentage of infected children is very similar to adults. This serological epidemiological study suggests that children are infected at the same rate as adults when exposed to an infection source. However, the disease is milder in children than adults since over $99 \%$ of minors showed mild or no symptoms ${ }^{137}$. Therefore, it is possible that the reason for the earlier results from China, Italy, and the USA, which reported low rates of pediatric COVID-19 cases $^{138-140}$, was testing mostly symptomatic cases. It is important not to dismiss without careful analysis the possibility of children, especially older children, being asymptomatic spreaders since school outbreaks have already been reported in some countries, such as New Zealand, Chile, and Israel ${ }^{141}$.

Recently, SARS-CoV-2 has also been implicated as the likely cause of a newly recognized pediatric syndrome. In late April, cases of rare symptoms similar to Kawasaki disease (KD) and toxic shock syndrome 
associated with COVID-19 were reported in children from the UK and Italy ${ }^{142,143}$. Shortly after, New York City also reported several cases, and the NYC Health Department and CDC alerted doctors of a multisystem inflammatory syndrome in children (MIS-C) ${ }^{144-146}$, which was called Pediatric Inflammatory Multisystem Syndrome temporally associated with SARS-CoV-2 (PIMS-TS) in Britain. Cases have now been reported in France, Switzerland, and Spain, and most affected children did not have underlying comorbidities ${ }^{147,148}$. Patients were positive for SARS-CoV-2 either by PCR or antibodies, but symptoms presented as a post-infection condition and not during the acute infection in most cases. Even when the epidemiologic evidence implicates SARS-CoV-2 as the most likely cause of MIS-C, causality has not yet been established. MIS-C symptoms resemble toxic shock syndrome, KD, and secondary hemophagocytic lymphohistiocytosis/macrophage activation syndrome $e^{145,149,150}$. This condition is characterized by prolonged fever ( $>4$ days) without a clear cause, inflammation symptoms such as rashes, conjunctivitis, swollen hands and feet, and swollen lymph nodes. The cytokine expression pattern observed in MIS-C suggests an IFN signaling component, along with IL-6 and IL-10 production, similar to KD and acute pulmonary COVID-19 infection. However, the lack of elevated TNF- $\alpha$ or IL-13 levels may differ from acute pulmonary COVID infections ${ }^{144}$. GI symptoms such as abdominal pain, vomiting, and diarrhea are common. Inflammation of blood vessels, including coronary arteries, has been observed, and cardiac problems tend to show earlier than in KD. Treatments used so far include steroids and intravenous immunoglobulin, high doses of aspirin, and antibiotics. The long-term effects are still unclear, but several patients tend to develop heart problems and low blood pressure, suggesting that children with serious heart damage will most probably need monitoring ${ }^{145}$. The increasing prevalence of MIS-C is suggestive of a delayed hyperimmune response to SARS-CoV-2 infection. However, the exact incidence of MIS-C after asymptomatic or mildly symptomatic infection with SARS-CoV-2 is not known.

\section{Risk factors}

In the earliest report from Wuhan, China, risk factors for mortality in adult patients showed that $48 \%$ of hospitalized patients had at least one comorbidity. Hypertension was the most common (30\%), followed by diabetes (19\%) and coronary heart disease $(8 \%)$. However, they reported that in-hospital death is associated with older age, a higher Sequential Organ Failure Assessment score, and D-dimer levels $>1 \mu \mathrm{g} /$ $\mathrm{ml}$ on admission ${ }^{151}$.

In the quest to further understand how viral and host factors relate to the clinical outcome of COVID-19 patients, a study analyzing clinical, molecular, and immunological data from 326 Shanghai positive patients was conducted, including an analysis of the isolated genomic sequences from the viral samples. They found that patients were exposed to different viral genetic variants in the early phases of the outbreak. However, this situation did not affect the patient's outcome. The risk factors that they found to be predictive of disease progression were lymphocytopenia, especially the reduction of $\mathrm{CD} 4+$ and $\mathrm{CD} 8+$ cells in patients upon hospital admission, and an extensive depletion of CD3+ T lymphocytes, linked to spikes in cytokines such as IL-6 and IL-8, associated with an adverse outcome. A higher risk for disease progression was associated with co-existing conditions such as age, comorbidities, and gender, with a higher risk for males. In this analysis, advanced age and lymphocytopenia were the two major independent risk factors, showing that disease severity determinants were related to the host and not to the viral genetic variant that infected them ${ }^{152}$.

The most extensive risk assessment analysis so far has been performed in England, with the OpenSAFELY platform, where they included more than 17 million people ( $40 \%$ of all their patients) linked to almost eleven thousand COVID-19-related deaths. In this analysis, most deaths were associated with male gender, advanced age, poverty, diabetes, obesity, and severe asthma, among other respiratory, neurologic, and chronic conditions. Strikingly, age was shown to be one of the highest risk factors: people older than 80 years were shown to be 20 times more likely to die from COVID-19 than 50-year-old people and 100 times more likely than those under 40 years of age. Hypertension as a risk factor was strongly related to age, obesity, and diabetes, and its risk factor ratio diminished when adjusted to the last two. Hypertension was also of greater risk in people up to 70 years of age and lower risk at older ages. Importantly, an association or the risk of death was also observed with nonwhite race and ethnicities, especially affecting Black and South Asian. This observation was sustained even after the adjustment of other risk factors, showing that only a small part of the excess risk is explained by the higher prevalence of medical problems and poverty ${ }^{153}$.

The ongoing COVID-19 pandemic caused by SARS-CoV-2 has infected more than 15 million people, 
resulting in over 600 thousand deaths in 188 countries, as of July 23,2020 . The pandemic has challenged the public health systems in all countries, with profound economic and political consequences, to a much greater extent, but with many parallels with the pandemic that was previously caused by SARS-CoV ${ }^{154}$. Much has been learned by the scientific and medical community about the biology, epidemiology, and pathogenesis of SARS-CoV-2 in the last 7 months; however, the evidence accumulated through nine decades of research on CoVs has served as the foundation for this new knowledge. Much of what was previously known for animal CoVs and the previously identified $\mathrm{HCoVs}$ has been confirmed for SARS-CoV-2 ${ }^{23}$. Research on SARS-CoV-2 has generated valuable but few new insights into the basic molecular biology and host-cell interactions of CoV, as much detail had been obtained previously. However, as SARS-CoV-2 catapults CoVs into notoriety, many new findings are likely to emerge in the near future, including a deeper understanding of the mechanisms that drive genome recombination and make CoVs highly adaptable to changes in tissue and host tropism and zoonotic episodes. Understanding the viral mechanisms responsible for alterations of cell functions during the infection will require the characterization of viral proteins that induce remodeling of cellular membranes during the formation of CoVs ROs, as these compartments direct viral genome replication and expression, conceal viral macromolecules from defense mechanisms, and are likely to regulate the innate cellular response. Although the evidence suggests that the immune system can generate protection against SARS-CoV-2, the production of antibodies seems to be short-lived, and the key role of the cellular response should be studied in further detail. Many aspects of the immunological response need to be further explored, as the symptoms and outcomes from the disease vary widely. The ability of SARS-CoV-2 to infect and replicate in the upper respiratory tract may be associated with milder symptoms but is likely to result in more efficient transmission. More severe COVID-19 symptoms may result from the lower respiratory tract infection, where the virus can also replicate. Moreover, it is clear that SARS-CoV-2 can infect other organs and is responsible for several extrapulmonary symptoms, although both organ and endothelial damage may be caused by the viral infection or the exacerbated hyperinflammatory immune response. Reports of coagulopathies in severe cases have been increasing, where clotting may be triggered by the viral infection or the ensuing inflammation. Although evidence suggests that children are mostly asymptomatic or have mild disease, much remains to be determined in terms of the age-groups at higher risk and may play important roles in transmission. Fewer infections or diseases in children may be due to differences in the pediatric immune response or differences in the susceptibility of infection, which may be linked to lower levels of ACE2 compared to adults. It is important to consider that asymptomatic children have been underrepresented in epidemiological studies, and different symptoms or disease presentations may be present in children, such as the inflammatory pediatric syndrome (MIS-C) that has been increasingly reported. Symptoms of MIS-C are similar, not identical, to KD and toxic shock syndrome. Many risk factors have been associated with severe or lethal outcomes of COVID-19, including obesity, diabetes, male gender, older age, and blood pressure-related diseases. However, social and racial factors (the latter, for the most part, probably related to race-related social inequalities) are now also considered to be important.

Clearly, important lessons can be learned from the SARS-CoV-2 pandemic: viral pandemics represent a permanent threat to human health, and the increased exposure of human populations to wild species of animals, either through commerce or occupation of new ecological niches, will increase the chances of zoonotic events. In addition, the ever-increasing human populations and continued occupation of new habitats, and the increased human mobility will contribute to the emergence of zoonotic viruses that infect humans. However, the accumulated knowledge of the biology and evolution of viruses can be used to understand fundamental aspects of viral emergence so that predictions can be made for potential emerging viruse ${ }^{155}$. For decades, virologists knew well that CoVs had zoonotic pandemic potential. However, no advances in multiple vaccine candidates were accomplished further than animal testing because they were deemed unnecessary and perhaps commercially unattractive. Therefore, it will be of foremost importance to establish a continued dialogue between the scientific community, health authorities, and policymakers so that the knowledge that is gained through scientific research can be harnessed for social benefit by ensuring preparedness of health systems capabilities and availability of effective vaccines and antivirals.

\section{Ethical disclosures}

Protection of human and animal subjects. The authors declare that no experiments were performed on humans or animals for this study. 
Confidentiality of data. The authors declare that they have followed the protocols of their work center on patient data publication.

Right to privacy and informed consent. The authors declare that no patient data appear in this article.

\section{Conflicts of interest}

The authors declare no conflict of interest.

\section{Funding}

Laboratory work is supported by CONACyT-SEP (A1S8696), CONACyT-SRE (S0016-280365), and CONACyT-BMBF (C0013-00267746), and RGLP by the Alexander von Humboldt Foundation. MVA receives a postdoctoral scholarship from CONACyT.

\section{Acknowledgments}

We apologize to all colleagues whose work could not be cited due to space limitations.

\section{References}

1. Mclntosh K, Chao RK, Krause HE, Wasil R, Mocega HE, Mufson MA Coronavirus infection in acute lower respiratory tract disease of infants. J Infect Dis. 1974;130:502-7.

2. Monto AS. Medical reviews. coronaviruses. Yale J Biol Med. 1974;47: 234-51.

3. Kapikian AZ. The Coronaviruses. Dev Biol Stand. 1975;28:42-64.

4. Sturman LS, Holmes KV. The molecular biology of Coronaviruses. Adv Virus Res. 1983;28:35-112.

5. Weiner LP. Coronaviruses: a historical perspective. In: Lai MM, Stohlman SA, editors. Coronaviruses. Advances in Experimental Medicine and Biology. Boston: Springer; 1987.

6. Lai MM, Cavanagh D. The molecular biology of coronaviruses. Adv Virus Res. 1997;48:1-100.

7. Masters PS. The molecular biology of coronaviruses. Adv Virus Res. 2006;66:193-292.

8. Liu L. Fields virology. Clin Infect Dis. 2014;59:613.

9. Beach JR. A filtrable virus, the cause of infectious laryngotracheitis of chickens. J Exp Med. 1931;54:809-16.

10. Baudette FR, Hudson CB. New recognized poultry disease. N Am Vet. 1933; $14: 50-4$

11. Baudette FR, Hudson $C B$. Cultivation of the virus of infectious bronchitis. J Am Vet Med Assoc. 1937;90:51-60.

12. Cheever FS, Daniels JB, Pappenheimer AM, Bailey OT. A murine virus (JHM) causing disseminated encephalomyelitis with extensive destruction of myelin. J Exp Med. 1949;90:181-210.

13. Bailey OT, Pappenheimer AM, Cheever FS, Daniels JB. A murine virus (JHM) causing disseminated encephalomyelitis with extensive destruction of myelin: II. Pathology. J Exp Med. 1949;90:195-212.

14. Gledhill AW, Andrewes $\mathrm{CH}$. A hepatitis virus of mice. Br J Exp Pathol. 1951;32:559-68.

15. Hartley JW, Rowe WP, Bloom HH, Turner HC. Antibodies to mouse hepatitis viruses in human sera. Proc Soc Exp Biol Med. 1964;115: 414-8.

16. Tyrrell DA, Bynoe ML. Cultivation of a novel type of common-cold virus in organ cultures. Br Med J. 1965;1:1467-70.

17. McIntosh K, Dees JH, Becker WB, Kapikian AZ, Chanock RM. Recovery in tracheal organ cultures of novel viruses from patients with respiratory disease. Proc Natl Acad Sci USA. 1967;57:933-40.

18. Hamre $D$, Procknow JJ. A new virus isolated from the human respiratory tract. Proc Soc Exp Biol Med. 1966;121:190-3.
19. Virology: Coronaviruses. Nature. 1968;220:650. https://doi.org/10.1038/220650b0.

20. Perlman S, Netland J. coronaviruses post-SARS: update on replication and pathogenesis. Nat Rev Microbiol. 2009;7:439-50.

21. Lim YX, Ng YL, Tam JP, Liu DX. Human Coronaviruses: a review of virus-host interactions. Diseases. 2016;4:1-28.

22. Fung TS, Liu DX. Human coronavirus: host-pathogen interaction. Annu Rev Microbiol. 2019;73:529-57.

23. Decaro N, Lorusso A. Novel human coronavirus (SARS-CoV-2): a lesson from animal Coronaviruses. Vet Microbiol. 2020;244:1-18.

24. Ksiazek TG, Erdman D, Goldsmith CS, Zaki SR, Peret T, Emery S, et al. A novel coronavirus associated with severe acute respiratory syndrome. N Engl J Med. 2003;348:1953-66.

25. Fouchier RA, Hartwig NG, Bestebroer TM, Niemeyer B, de Jong JC, Simon $\mathrm{JH}$, et al. A previously undescribed coronavirus associated with respiratory disease in humans. Proc Natl Acad Sci USA. 2004;101:6212-6.

26. Woo PC, Lau SK, Chu CM, Chan KH, Tsoi HW, Huang Y, et al. Characterization and complete genome sequence of a novel coronavirus, coronavirus HKU1, from patients with pneumonia. J Virol. 2005;79:884-95

27. Zaki AM, van Boheemen S, Bestebroer TM, Osterhaus AD, Fouchier RA. Isolation of a novel coronavirus from a man with pneumonia in Saudi Arabia. N Engl J Med. 2012;367:1814-20.

28. Vijgen L, Keyaerts E, Moes E, Thoelen I, Wollants E, Lemey P, et al. Complete genomic sequence of human coronavirus OC43: molecular clock analysis suggests a relatively recent zoonotic Coronavirus transmission event. J Virol. 2005;79:1595-604.

29. Ziebuhr J. The coronavirus replicase. Curr Top Microbiol Immunol. 2005;287:57-94

30. Knoops K, Kikkert M, Worm SH, Zevenhoven-Dobbe JC, van der Meer $Y$, Koster AJ, et al. SARS-coronavirus replication is supported by a reticulovesicular network of modified endoplasmic reticulum. PLOS Biol. 2008;6:1957-74.

31. Cong Y, Ulasli M, Schepers H, Mauthe M, V'Kovski P, Kriegenburg F, et al. Nucleocapsid protein recruitment to replication-transcription complexes plays a crucial role in coronaviral life cycle. J Virol. 2020;94:1-21.

32. Sanchez EL, Lagunoff M. Viral activation of cellular metabolism. Virology. 2015; 479-480:609-18.

33. Albrecht T, Fons M, Boldogh I, Rabson AS. In: Baron SM, editor. Effects on Cells. Galveston, TX: University of Texas Medical Branch at Galveston; 1996.

34. Netherton CL, Wileman T. Virus factories, double membrane vesicles and viroplasm generated in animal cells. Curr Opin Virol. 2011;1:381-7.

35. Ivanovic T, Boulant S, Ehrlich M, Demidenko AA, Arnold MM, Kirchhausen $\mathrm{T}$, et al. Recruitment of cellular clathrin to viral factories and disruption of clathrin-dependent trafficking. Traffic. 2011;12:1179-95.

36. Schmid M, Speiseder T, Dobner T, Gonzalez RA. DNA virus replication compartments. J Virol. 2014;88:1404-20.

37. Paul D, Bartenschlager R. Flaviviridae replication organelles: oh, what a tangled web we weave. Annu Rev Virol. 2015;2:289-310.

38. Harak C, Lohmann V. Ultrastructure of the replication sites of positive-strand RNA viruses. Virology. 2015;479-480:418-33.

39. Hagemeijer MC, Rottier PJ, de Haan CA. Biogenesis and dynamics of the coronavirus replicative structures. Viruses. 2012;4:3245-69.

40. Snijder EJ, Limpens R, de Wilde AH, de Jong AW, Zevenhoven-Dobbe JC, Maier $\mathrm{HJ}$, et al. A unifying structural and functional model of the Coronavirus replication organelle: tracking down RNA synthesis. PLoS Biol. 2020;18:1-25

41. Hagemeijer MC, Monastyrska I, Griffith J, van der Sluijs P, Voortman J, van Bergen en Henegouwen PM, et al. Membrane rearrangements mediated by coronavirus nonstructural proteins 3 and 4. Virology. 2014;458459:125-35.

42. Hurst KR, Koetzner CA, Masters PS. Characterization of a critical interaction between the coronavirus nucleocapsid protein and nonstructural protein 3 of the viral replicase-transcriptase complex. J Virol. 2013;87:9159-72.

43. V'Kovski P, Gerber M, Kelly J, Pfaender S, Ebert N, Lagache SB, et al. Determination of host proteins composing the microenvironment of coronavirus replicase complexes by proximity-labeling. Elife. 2019;8:1-30.

44. van Hemert MJ, van den Worm SH, Knoops K, Mommaas AM, Gorbalenya AE, Snijder EJ. SARS-coronavirus replication/transcription complexes are membrane-protected and need a host factor for activity in vitro. PLoS Pathog. 2008;4:e1000054.

45. Fung TS, Huang M, Liu DX. Coronavirus-induced ER stress response and its involvement in regulation of coronavirus-host interactions. Virus Res. 2014;194:110-23.

46. Jordan R, Wang L, Graczyk TM, Block TM, Romano PR. Replication of a cytopathic strain of bovine viral diarrhea virus activates PERK and induces endoplasmic reticulum stress-mediated apoptosis of MDBK cells. J Virol. 2002;76:9588-99.

47. Versteeg GA, van de Nes PS, Bredenbeek PJ, Spaan WJ. The coronavirus spike protein induces endoplasmic reticulum stress and upregulation of intracellular chemokine mRNA concentrations. J Virol. 2007;81:10981-90.

48. Minakshi R, Padhan K Rani M, Khan N, Ahmad F, Jameel S. The SARS Coronavirus 3 a protein causes endoplasmic reticulum stress and induces ligand-independent downregulation of the Type 1 interferon receptor. PLoS One. 2009;4:1-10 
49. Shi CS, Nabar NR, Huang NN, Kehrl JH. SARS-Coronavirus open reading frame-8b triggers intracellular stress pathways and activates NLRP3 inflammasomes. Cell Death Discov. 2019;5:101.

50. Harding HP, Zhang $Y$, Bertolotti A, Zeng H, Ron D. Perk is essential for translational regulation and cell survival during the unfolded protein response. Mol Cell. 2000;5:897-904.

51. Siu KL, Kok KH, Ng MH, Poon VK, Yuen KY, Zheng BJ, et al. Severe acute respiratory syndrome coronavirus $M$ protein inhibits Type I interferon production by impeding the formation of TRAF3.TANK.TBK1/IKKepsilon complex. J Biol Chem. 2009;284:16202-9.

52. Vabret N, Britton GJ, Gruber C, Hegde S, Kim J, Kuksin M, et al. Immunology of COVID-19: current state of the science. Immunity. 2020;52:910-41.

53. Yazdanpanah F, Hamblin MR, Rezaei N. The immune system and COVID-19: friend or foe? Life Sci. 2020;256:117900.

54. Hackbart M, Deng X, Baker SC. Coronavirus endoribonuclease targets viral polyuridine sequences to evade activating host sensors. Proc Nat Acad Sci USA. 2020;117:8094-103

55. Kindler E, Gil-Cruz C, Spanier J, Li Y, Wilhelm J, Rabouw HH, et al. Early endonuclease-mediated evasion of RNA sensing ensures efficient coronavirus replication. PLoS Pathog. 2017;13:e1006195.

56. Liu XY, Wei B, Shi HX, Shan YF, Wang C. Tom70 mediates activation of interferon regulatory factor 3 on mitochondria. Cell Res. 2010;20:994-1011.

57. Gordon DE, Jang GM, Bouhaddou M, Xu J, Obernier K, White KM, et al. A SARS-CoV-2 protein interaction map reveals targets for drug repurposing. Nature. 2020;583:459-68.

58. Dorward DA, Russell CD, Um IH, Elshani M, Armstrong SD, Penrice-Randal $\mathrm{R}$, et al. Tissue-specific immunopathology in fatal COVID-19. Am J Respir Crit Care Med. 2021;203:192-201. doi:10.1164/rccm.202008-3265OC.

59. Blanco-Melo D, Nilsson-Payant BE, Liu WC, Uhl S, Hoagland D, Moller R, et al. Imbalanced host response to SARS-CoV-2 drives development of COVID-19. Cell. 2020;181:1036-45

60. Tay MZ, Poh CM, Renia L, MacAry PA, Ng LF. The trinity of COVID-19: immunity, inflammation and intervention. Nat Rev Immunol. 2020;20:363-74.

61. Long QX, Tang XJ, Shi QL, Li Q, Deng HJ, Yuan J, et al. Clinical and immunological assessment of asymptomatic SARS-CoV-2 infections. Nat Med. 2020;26:1200-4

62. Long QX, Liu BZ, Deng HJ, Wu GC, Deng K, Chen YK, et al. Antibody responses to SARS-CoV-2 in patients with COVID-19. Nat Med. 2020;26:845-8.

63. Shang J, Wan Y, Luo C, Ye G, Geng Q, Auerbach A, et al. Cell entry mechanisms of SARS-CoV-2. Proc Natl Acad Sci USA. 2020;117: 11727-34

64. Manners C, Bautista EL, Sidoti H, Lopez OJ. Protective adaptive immunity against severe acute respiratory syndrome coronaviruses 2 (SARSCoV-2) and implications for vaccines. Cureus. 2020;12:e8399.

65. Eroshenko N, Gill T, Keaveney MK, Church GM, Trevejo JM, Rajaniemi H Implications of antibody-dependent enhancement of infection for SARSCoV-2 countermeasures. Nat Biotech. 2020;38:789-91.

66. Wang X, Xu W, Hu G, Xia S, Sun Z, Liu Z, et al. Retracted article. SARSCoV-2 infects $T$ lymphocytes through its spike protein-mediated membrane fusion. Cell Mol Immunol. 2020; Retracted article, doi: 10.1038/ s41423-020-0424-9

67. Guihot A, Litvinova E, Autran B, Debré P, Vieillard V. Cell-mediated immune responses to COVID-19 infection. Front Immunol. 2020;11:1662.

68. Ni L, Ye F, Cheng ML, Feng Y, Deng YQ, Zhao H, et al. Detection of SARS-CoV-2-specific humoral and cellular immunity in COVID-19 convalescent individuals. Immunity. 2020;52:971-7.

69. Prompetchara E, Ketloy C, Palaga T. Immune responses in COVID-19 and potential vaccines: lessons learned from SARS and MERS epidemic. Asian Pac J Allergy Immunol. 2020;38:1-9.

70. Rokni M, Ghasemi V, Tavakoli Z. Immune responses and pathogenesis of SARS-CoV-2 during an outbreak in Iran: comparison with SARS and MERS. Rev Med Virol. 2020;30:e2107.

71. Grifoni A, Weiskopf D, Ramirez SI, Mateus J, Dan JM, Moderbacher CR, et al. Targets of T cell responses to SARS-CoV-2 coronavirus in humans with COVID-19 disease and unexposed individuals. Cell. 2020:181:1489-501.e15.

72. Lv H, Wu NC, Tsang OT, Yuan M, Perera R, Leung WS, et al. Cross-reactive antibody response between SARS-CoV-2 and SARS-CoV infections. Cell Rep. 2020;31:107725.

73. Grimsholm O, Mortari EP, Davydov AN, Shugay M, Obraztsova AS Bocci C, et al. The interplay between CD27 (dull) and CD27 (bright) B cells ensures the flexibility, stability, and resilience of human $B$ cell memory. Cell Rep. 2020:30:2963-77.

74. Carsetti R, Quintarelli C, Quinti I, Mortari EP, Zumla A, Ippolito G, et al. The immune system of children: the key to understanding SARS-CoV-2 susceptibility? Lancet Child Adolesc Health. 2020;4:414-6.

75. Xiong $Y$, Liu $Y$, Cao L, Wang D, Guo M, Jiang A, et al. Transcriptomic characteristics of bronchoalveolar lavage fluid and peripheral blood mononuclear cells in COVID-19 patients. Emerg Microbes Infect. 2020;9:761-70.

76. Freundt EC, Li Y, Lippincott-Schwartz J, Zaki SR, Xiao-Ning X, Baric RS et al. The open reading frame $3 a$ protein of severe acute respiratory syndrome-associated coronavirus promotes membrane rearrangement and cell death. J Virol. 2010;84:1097-109.
77. Ren $Y$, Shu T, Wu D, Mu J, Wang $C$, Huang M, et al. The ORF3a protein of SARS-CoV-2 induces apoptosis in cells. Cell Mol Immunol. 2020;17:881-3.

78. Huang $\mathrm{C}$, Wang $\mathrm{Y}$, Li X, Ren L, Zhao J, Hu Y, et al. Clinical features of patients infected with 2019 novel coronavirus in Wuhan, China. Lancet. 2020;395:497-506

79. McAloon C, Collins I, Hunt K, Barber A, Byrne AW, Butler F, et al. The incubation period of COVID-19: a rapid systematic review and meta-analysis of observational research. BMJ Open. 2020;10:e039652.

80. Meyerowitz-Katz G, Merone L. A systematic review and meta-analysis of published research data on COVID-19 infection-fatality rates. Int J Infect Dis. 2020;101:138-48.

81. Heller L, Mota CR, Greco DB. COVID-19 faecal-oral transmission: are we asking the right questions? Sci Total Environ. 2020;729:1-3.

82. Jayaweera M, Perera $H$, Gunawardana B, Manatunge J. Transmission of COVID-19 virus by droplets and aerosols: a critical review on the unresolved dichotomy. Environ Res. 2020;188:109819.

83. Sungnak W, Huang N, Bcavin C, Berg M, Queen R, Litvinukova M, et al. SARS-CoV-2 entry factors are highly expressed in nasal epithelial cells together with innate immune genes. Nat Med. 2020;26:681-7.

84. Wolfel R, Corman VM, Guggemos W, Seilmaier M, Zange S, Muller MA et al. Virological assessment of hospitalized patients with COVID-2019. Nature. 2020;581:465-9.

85. He X, Lau EH, Wu P, Deng X, Wang J, Hao X, et al. Temporal dynamics in viral shedding and transmissibility of COVID-19. Nat Med. 2020;26:1491-3

86. Ding $\mathrm{Y}$, Wang H, Shen $\mathrm{H}$, Li Z, Geng J, Han H, et al. The clinical pathology of severe acute respiratory syndrome (SARS): a report from China. J Pathol. 2003;200:282-9.

87. Ng DL, Hosani FA, Keating MK, Gerber SI, Jones TL, Metcalfe MG. Clinicopathologic, immunohistochemical, and ultrastructural findings of a fatal case of middle east respiratory syndrome coronavirus infection in the United Arab Emirates, April 2014. Am J Pathol. 2016;186:652-8.

88. Dorward DA, Russell CD, Um IH, Elshani M, Armstrong SD, Penrice-Randal R, et al. Tissue-Specific Tolerance in Fatal COVID-19. Am J Respir Crit Care Med. doi: 10.1164/rccm.202008-32650C

89. Gupta A, Madhavan MV, Sehgal K, Nair N, Mahajan S, Sehrawat TS, et al. Extrapulmonary manifestations of COVID-19. Nat Med. 2020;26:1017-32.

90. Varga Z, Flammer AJ, Steiger P, Haberecker M, Andermatt R, Zinkernagel AS, et al. Endothelial cell infection and endotheliitis in COVID-19. Lancet. 2020;395:1417-8.

91. Mao R, Qiu Y, He JS, Tan JY, Li XH, Liang J, et al. Manifestations and prognosis of gastrointestinal and liver involvement in patients with $\mathrm{CO}$ VID-19: a systematic review and meta-analysis. Lancet Gastroenterol Hepatol. 2020:5:667-78.

92. Redd WD, Zhou JC, Hathorn KE, McCarty TR, Bazarbashi AN, Thompson $\mathrm{CC}$, et al. Prevalence and characteristics of gastrointestinal symptoms in patients with SARS-CoV-2 infection in the United States: a multicenter cohort study. Gastroenterology. 2020;159:675-7.

93. Assiri A, Al-Tawfiq JA, Al-Rabeeah AA, Al-Rabiah FA, Al-Hajjar S, Al-Ba$\operatorname{rrak} A$, et al. Epidemiological, demographic, and clinical characteristics of 47 cases of Middle East respiratory syndrome coronavirus disease from Saudi Arabia: a descriptive study. Lancet Infect Dis. 2013;13:752-61.

94. Booth CM, Matukas LM, Tomlinson GA, Rachlis AR, Rose DB, Dwosh HA, et al. Clinical features and short-term outcomes of 144 patients with SARS in the greater Toronto area. JAMA. 2003;289:2801-9.

95. Hajifathalian K, Mahadev S, Schwartz RE, Shah S, Sampath K, SchnoII-Sussman F, et al. SARS-COV-2 infection (Coronavirus disease 2019) for the gastrointestinal consultant. World J Gastroenterol. 2020;26:1546-53.

96. Liya G, Yuguang W, Jian L, Huaiping Y, Xue H, Jianwei H, et al. Studies on viral pneumonia related to novel coronavirus SARS-CoV-2, SARSCoV, and MERS-CoV: a literature review. APMIS. 2020;128:423-32.

97. Xiao F, Tang M, Zheng X, Liu Y, Li X, Shan H. Evidence for gastrointestinal infection of SARS-CoV-2. Gastroenterology. 2020;158:1831-3.

98. Ziegler CG, Allon SJ, Nyquist SK, Mbano IM, Miao VN, Tzouanas CN, et al. SARS-CoV-2 receptor ACE2 is an interferon-stimulated gene in muman airway epithelial cells and is detected in specific cell subsets across tissues. Cell. 2020;181:1016-35.

99. Oxley TJ, Mocco J, Majidi S, Kellner CP, Shoirah H, Singh IP, et al. Large-vessel stroke as a presenting feature of COVID-19 in the young. N Engl J Med. 2020;382:e60

100. Yaghi S, Ishida K, Torres J, Mac Grory B, Raz E, Humbert K, et al. SARSCoV-2 and stroke in a New York healthcare system. Stroke. 2020:51:2002-11.

101. Toscano G, Palmerini F, Ravaglia S, Ruiz L, Invernizzi P, Cuzzoni MG, et al. Guillain-Barré syndrome associated with SARS-CoV-2. N Engl J Med. 2020;382:2574-6.

102. Zhao H, Shen D, Zhou H, Liu J, Chen S. Guillain-Barré syndrome associated with SARS-CoV-2 infection: causality or coincidence? Lancet Neurol. 2020;19:383-4.

103. Helms J, Kremer S, Merdji H, Clere-Jehl R, Schenck M, Kummerlen C et al. Neurologic features in severe SARS-CoV-2 infection. N Engl J Med. 2020;382:2268-70. 
104. Moriguchi T, Harii N, Goto J, Harada D, Sugawara H, Takamino J, et al. A first case of meningitis/encephalitis associated with SARS-Coronavirus-2. Int J Infect Dis. 2020;94:55-8.

105. Franceschi AM, Ahmed O, Giliberto L, Castillo M. Hemorrhagic posterio reversible encephalopathy syndrome as a manifestation of COVID-19 infection. AJNR Am J Neuroradiol. 2020;41:1173-6.

106. Poyiadji N, Shahin G, Noujaim D, Stone M, Patel S, Griffith B. COVID-19-associated acute hemorrhagic necrotizing encephalopathy: CT and MRI. Radiology. 2020;296:E119-20.

107. Desforges M, Le Coupanec A, Stodola J, Meessen-Pinard M, Talbot P. Human coronaviruses: viral and cellular factors involved in neuroinvasiveness and neuropathogenesis. Virus Res. 2014;194:145-58.

108. Gu J, Gong E, Zhang B, Zheng J, Gao Z, Zhong Y, et al. Multiple organ infection and the pathogenesis of SARS. J Exp Med. 2005;202:415-24

109. Li YC, Bai WZ, Hashikawa T. The neuroinvasive potential of SARS-CoV2 may play a role in the respiratory failure of COVID-19 patients. J Med Virol. 2020;92:552-5.

110. Baig AM, Khaleeg A, Ali U, Syeda $H$. Evidence of the COVID-19 virus targeting the CNS: tissue distribution, host-virus interaction, and proposed neurotropic mechanisms. ACS Chem Neurosci. 2020;11:995-8.

111. Guan W, Ni Z, Hu Y, Liang W, Ou C, He J, et al. Clinical characteristics of coronavirus disease 2019 in China. N Engl J Med. 2020;382:1708-20.

112. Zhou $X$, Li Y, Yang Q. Antiplatelet therapy after percutaneous coronary intervention in patients with COVID-19: implications from clinical features to pathologic findings. Circulation. 2020;141:1736-8.

113. Klok FA, Kruip MJ, van der Meer NJ, Arbous MS, Gommers DA Kant KM, et al. Incidence of thrombotic complications in critically ill ICU patients with COVID-19. Thromb Res. 2020;191:145-7.

114. Poissy J, Goutay J, Caplan M, Parmentier E, Duburcq T, Lassalle F, et al. Pulmonary embolism in COVID-19 patients: awareness of an increased prevalence. Circulation. 2020;142:184-6.

115. Parikh SA. Intermediate or Prophylactic-Dose Anticoagulation for Venous or Arterial Thromboembolism in Severe COVID-19 (IMPROVE). New York: Columbia University; 2020. Available from: https://www.clinicaltrials.gov.

116. Giannis D, Ziogas IA, Gianni $P$. Coagulation disorders in coronavirus infected patients: COVID-19, SARS-CoV-1, MERS-CoV and lessons from the past. J Clin Virol. 2020;127:104362.

117. Ng LF, Hibberd ML, Ooi EE, Tang KF, Neo SY, Tan J. A human in vitro model system for investigating genome-wide host responses to SARS coronavirus infection. BMC Infect Dis. 2004;4:34.

118. Tang BS, Chan KH, Cheng VC, Woo PC, Lau SK, Lam CC, et al. Comparative host gene transcription by microarray analysis early after infection of the Huh7 cell line by SARS coronavirus and human coronavirus 229E. J Virol. 2005;79:6180-93.

119. Han M, Yan W, Huang Y, Yao H, Wang Z, Xi D, et al. The nucleocapsid protein of SARS-CoV induces transcription of hfgl2 prothrombinase gene dependent on C/EBP alpha. J Biochem. 2008;144:51-62.

120. Li K, Wohlford-Lenane C, Perlman S, Zhao J, Jewell AK, Reznikov LR, et al. Middle east respiratory syndrome coronavirus causes multiple organ damage and lethal disease in mice transgenic for human dipeptidyl peptidase 4. J Infect Dis. 2015;213:712-22.

121. Ferrario CM, Jessup J, Chappell MC, Averill DB, Brosnihan KB, Tallant EA, et al. Effect of angiotensin-converting enzyme inhibition and angiotensin II receptor blockers on cardiac angiotensin-converting enzyme 2. Circulation. 2005;111:2605-10.

122. Monteil V Kwon $\mathrm{H}$, Prado $\mathrm{P}$, Hagelkrys A, Wimmer RA, Stahl M, et al. Inhibition of SARS-CoV-2 infections in engineered human tissues using clinical-grade soluble human ACE2. Cell. 2020;181:905-13.

123. Magro C, Mulvey JJ, Berlin D, Nuovo G, Salvatore S, Harp J, et al. Complement associated microvascular injury and thrombosis in the pathogenesis of severe COVID-19 infection: a report of five cases. Trans Res. 2020;220:1-13

124. Ludvigsson JF. Systematic review of COVID-19 in children shows milder cases and a better prognosis than adults. Acta Paediatr. 2020;109:1088-95.

125. Götzinger F, Santiago-Garcia B, Noguera-Julian A, Lanaspa M, Lancella L, Carducci FI, et al. COVID-19 in children and adolescents in Europe: a multinational, multicentre cohort study. Lancet Child Adolesc Health. 2020;4:653-61.

126. Lingappan K, Karmouty-Quintana H, Davies J, Akkanti B, Harting MT. Understanding the age divide in COVID-19: why are children overwhelmingly spared? Am J Physiol Lung Cell Mol Physiol. 2020;319:L39-44.

127. Zhu L, Lu X, Chen L. Possible causes for decreased susceptibility of children to coronavirus. Pediatr Res. 2020:88:342.

128. Nagata N, Iwata N, Hasegawa H, Fukushi S, Harashima A, Sato Y, et al. Mouse-passaged severe acute respiratory syndrome-associated coronavirus leads to lethal pulmonary edema and diffuse alveolar damage in adult but not young mice. Am J Pathol. 2008;172:1625-37.

129. Smith LS, Gharib SA, Frevert CW, Martin TR. Effects of age on the synergistic interactions between lipopolysaccharide and mechanical ventilation in mice. Am J Respir Cell Mol Biol. 2010;43:475-86.

130. Aranburu A, Mortari EP, Baban A, Giorda E, Cascioli S, Marcellini V, et al. Human B-cell memory is shaped by age-and tissue-specific T-independent and GC-dependent events. Eur J Immunol. 2017:47:327-44.
131. Capolunghi F, Rosado MM, Sinibaldi M, Aranburu A, Carsetti R. Why do we need IgM memory B cells? Immunol Lett. 2013;152:114-20.

132. Kotylo PK, Fineberg NS, Freeman KS, Redmond NL, Charland C. Reference ranges for lymphocyte subsets in pediatric patients. Am J Clin Pathol. 1993;100:111-5

133. Wang A, Chiou J, Poirion OB, Buchanan J, Valdez MJ, Verheyden JM, et al. Single-cell multiomic profiling of human lungs reveals cell-type-specific and age-dynamic control of SARS-CoV2 host genes. Elife. 2020;9:e62522. doi: 10.7554/eLife.62522.

134. Muus C, Luecken MD, Eraslan G, Waghray A, Heimberg G, Sikkema L, et al. Integrated Analyses of Single-Cell Atlases Reveal Age, Gender, and Smoking Status Associations with Cell Type-Specific Expression of Mediators of SARSCoV-2 Viral Entry and Highlights Inflammatory Programs in Putative Target Cells, bioRxiv; 2020. Preprint that has not been certified by peer review.

135. Li G, He X, Zhang L, Ran Q, Wang J, Xiong A. Assessing ACE2 expression patterns in lung tissues in the pathogenesis of COVID-19. J Autoimmun. 2020;112:102463.

136. Lee $B$, Raszka WV. COVID-19 transmission and children: the child is not to blame. Pediatrics. 2020;146:e2020004879.

137. Sant Joan De Déu Hospital. Kids Corona. Barcelona: Sant Joan De Déu Hospital; 2020. Available from: https://www.sjdhospitalbarcelona.org/es/ kidscorona.

138. Bialek S, Gierke R, Hughes M, McNamara LA, Pilishvili T, Skoff T. Coronavirus disease 2019 in children-United States, February 12-April 2 , 2020. MMWR Morb Mortal Wkly Rep. 2020;69:422-6.

139. Grasselli G, Zangrillo A, Zanella A, Antonelli M, Cabrini L, Castelli A, et al. Baseline characteristics and outcomes of 1591 patients infected with SARS-CoV-2 admitted to ICUs of the Lombardy Region, Italy. JAMA. 2020;323:1574-81

140. Li Q, Guan X, Wu P, Wang X, Zhou L, Tong Y, et al. Early transmission dynamics in Wuhan, China, of novel coronavirus-infected pneumonia. $\mathrm{N}$ Engl J Med. 2020;382:1199-207.

141. Torres JP, Piñera C, de la Maza V, Lagomarcino AJ, Simian D, Torres B, et al. SARS-CoV-2 antibody prevalence in blood in a large school community subject to a COVID-19 outbreak: a cross-sectional study. Clin Infect Dis. 2020; In press, doi:10.1093/cid/ciaa955.

142. Riphagen S, Gomez X, Gonzalez-Martinez C, Wilkinson N, Theocharis P. Hyperinflammatory shock in children during COVID-19 pandemic. Lancet. 2020;395:1607-8.

143. Verdoni L, Mazza A, Gervasoni A, Martelli L, Ruggeri M, Ciuffreda M, et al. An outbreak of severe Kawasaki-like disease at the Italian epicentre of the SARS-CoV-2 epidemic: an observational cohort study. Lancet. 2020;395:1771-8.

144. Cheung EW, Zachariah P, Gorelik M, Boneparth A, Kernie SG, Orange JS, et al. Multisystem inflammatory syndrome related to COVID-19 in previously healthy children and adolescents in New York City. JAMA. 2020;324:294-6.

145. Riollano-Cruz M, Akkoyun E, Briceno-Brito E, Kowalsky S, Posada R, Sordillo EM, et al. Multisystem inflammatory syndrome in children (MIS-C) related to COVID-19: a New York City experience. J Med Virol. 2020; In press, doi:10.1002/jmv.26224.

146. 2020 Health Alert \#13: Pediatric Multisystem Inflammatory Syndrome Potentially Associated with COVID-19. New York: New York City Health Department; 2020. p. 1-2. Available from: https://www.nyc.gov/2020.

147. Belhadjer Z, Méot M, Bajolle F, Khraiche D, Legendre A, Abakka S, et al Acute heart failure in multisystem inflammatory syndrome in children in the context of global SARS-CoV-2 pandemic. Circulation. 2020;142:429-36.

148. Toubiana J, Poirault C, Corsia A, Bajolle F, Fourgeaud J, Angoulvant F, et al. Kawasaki-like multisystem inflammatory syndrome in children during the covid-19 pandemic in Paris, France: prospective observational study. BMJ. 2020;369:m2094. doi: 10.1136/bmj.m2094.

149. Whittaker E, Bamford A, Kenny J, Kaforou M, Jones CE, Shah P, et al. Clinical characteristics of 58 children with a pediatric inflammatory multisystem syndrome temporally associated with SARS-CoV-2. JAMA. 2020;324:259-69.

150. Nakra NA, Blumberg DA, Herrera-Guerra A, Lakshminrusimha S. Multi-system inflammatory syndrome in children (MIS-c) following SARSCoV-2 infection: review of clinical presentation, hypothetical pathogenesis, and proposed management. Children (Basel). 2020;7:69.

151. Zhou F, Yu T, Du R, Fan G, Liu Y, Liu Z, et al. Clinical course and risk factors for mortality of adult inpatients with COVID-19 in Wuhan, China: a retrospective cohort study. Lancet. 2020;395:1054-62.

152. Zhang $X$, Tan Y, Ling Y, Lu G, Liu F, Yi Z, et al. Viral and host factors related to the clinical outcome of COVID-19. Nature. 2020;583:437-40.

153. Williamson EJ, Walker AJ, Bhaskaran K, Bacon S, Bates C, Morton CE, et al. Factors associated with COVID-19-related death using OpenSAFELY Nature 2020:584:430-6.

154. Forum on Microbial Threats, Board on Global Health, Institute of Medicine, National Academies of Sciences, Engineering, and Medicine. Global Health Risk Framework: Governance for Global Health: Workshop Summary. Washington, DC: National Academies Press; 2016.

155. Holmes EC, Rambaut A. Viral evolution and the emergence of SARS Coronavirus. Philos Trans R Soc Lond B Biol Sci. 2004;359:1059-65. 